\title{
Synthesized Nanorods Hydroxyapatite by Microwave-Assisted Technology for In Vitro Osteoporotic Bone Regeneration through Wnt/ $\beta$-Catenin Pathway
}

\author{
Nadia Z. Shaban ${ }^{1}$, Marwa Y. Kenawy ${ }^{1,2, *,+}$ D, Nahla A. Taha ${ }^{3}$, Mona M. Abd El-Latif ${ }^{2}$ \\ and Doaa A. Ghareeb $1,4,5,+$ (D) \\ 1 Biochemistry Department, Faculty of Science, Alexandria University, Alexandria 21511, Egypt; \\ nshaban2001@yahoo.co.uk (N.Z.S.); d.ghareeb@yahoo.com (D.A.G.) \\ 2 Fabrication Technology Researches Department, Advanced Technology and New Materials Research \\ Institute (ATNMRI), City of Scientific Research and Technological Applications (SRTA-City), \\ New Borg El-Arab 21934, Egypt; amona1911@yahoo.com \\ 3 Modeling and Simulation Research Department, Advanced Technology and New Materials Research \\ Institute (ATNMRI), City of Scientific Research and Technological Applications (SRTA-City), \\ New Borg El-Arab 21934, Egypt; nahlataha_1982@yahoo.com \\ 4 Bio-Screening and Preclinical Trial Lab, Biochemistry Department, Faculty of Science, Alexandria University, \\ Alexandria 21511, Egypt \\ 5 Center of Excellence for Drug Preclinical studies (CE-DPS), Pharmaceutical and Fermentation Industries \\ Development Center (PFIDC), City of Scientific Research and Technological Applications (SRTA-City), \\ New Borg El Arab 21934, Egypt \\ Citation: Shaban, N.Z.; Kenawy, \\ * Correspondence: mkenawy@srtacity.sci.eg \\ + Marwa Y. Kenawy and Doaa A. Ghareeb contributed equally to this manuscript.
} M.Y.; Taha, N.A.; Abd El-Latif, M.M.; Ghareeb, D.A. Synthesized Nanorods Hydroxyapatite by MicrowaveAssisted Technology for In Vitro Osteoporotic Bone Regeneration through Wnt/ $\beta$-Catenin Pathway. Materials 2021, 14, 5823.

https://doi.org/

10.3390/ma14195823

Academic Editors: Rumen Krastev and Xin Xiong

Received: 6 September 2021

Accepted: 1 October 2021

Published: 5 October 2021

Publisher's Note: MDPI stays neutral with regard to jurisdictional claims in published maps and institutional affiliations.

Copyright: (C) 2021 by the authors Licensee MDPI, Basel, Switzerland. This article is an open access article distributed under the terms and conditions of the Creative Commons Attribution (CC BY) license (https:/ / creativecommons.org/licenses/by/ $4.0 /)$.

Abstract: This research presents an optimal and inexpensive, without any additives, method for the synthesis and sintering of hydroxyapatite (HA) by microwave-assisted technology (MAT) furnace. The target sintering temperature of the furnace $\left(1100{ }^{\circ} \mathrm{C}\right)$ was held for one and two hours for conventional sintering. With regard to the microwave hybrid sintering, it was held at $100 \% \mathrm{MW}$ for 20 and $30 \mathrm{~min}$. FTIR, XRD, TGA, SEM/EDS, and TEM were assessed to determine HA phase composition, and structural as well as thermal decomposition behavior. The in vitro effects of sintered HA discs on cultured aged mice-isolated osteoblast cells and hydrocortisone-induced osteoclast cells were assessed by measuring ALP, osteocalcin, TRAP, calcium, and Alizarin red S staining. Moreover, their effects on cell differentiation (CD90 and CD 105 and PARR- $y$ ) and death markers (GSK3b, MAPK, and $\beta$-catenin) were evaluated. The results demonstrate the production of $\approx 35 \mathrm{~nm}$ crystalsized pure hydroxyapatite nanorod-like particles with a high degree of crystallinity and no impurities as required for biomedical application. HA increased osteogenesis (ALP, osteocalcin, and calcium) markers and decreased cell resorption markers. In addition, HA nanorods reversed the effect of cortisone on cell differentiation and death markers. In conclusion, microwave hybrid sintered HA is a potential nanomaterial for osteoporotic bone regeneration as HA reversed the cortisone adverse effect on osteoblast cell death through canonical and non-canonical pathways.

Keywords: biomaterials; bioceramics; sintering; glucocorticoid; osteoporosis; osteoblast; osteoclast; wnt pathway

\section{Introduction}

Bone is a mineralized connective tissue, containing about 69 wt \% mineral phase (hydroxyapatite, needle-shaped), a $22 \mathrm{wt} \%$ organic phase ( $90 \mathrm{wt} \%$ type I collagen, $\sim 5$ wt \% noncollagenous proteins (NCPs), $\sim 2$ wt \% lipids), and 9 wt \% water [1,2]. Bone displays four types of cells: osteoblasts, bone lining cells, osteocytes, and osteoclasts [3].

The most common metabolic bone disorder is osteoporosis, which is defined as bone quantity reduction. Worldwide, osteoporosis is a major fundamental cause of fractures in 
individuals over the age of 50 years and 200 million people are affected [4]. In the USA, the incidence of osteoporosis increased by 17.7\% during the period 2004-2013 [5]. According to the statistical analysis of the Egyptian Osteoporosis Prevention Society, osteoporosis affects one in three women and one in five men. In Egypt, 53.9\% of postmenopausal women have osteopenia and $28.4 \%$ have osteoporosis [6]. By 2050, the number of patients will increase annually by 21.3 million [4] as the number of elderly patients (over 50 years) will increase dramatically. For instance, the number in Australia will increase by $4 \%$ until it reaches 40 in the next years while in Arabic countries this percent will range between 30 and 40\% [4].

Half of the survivors are incapable to walk, and $25 \%$ are kept in long-term care in a nursing home and this influences the economy as by 2050 about $80-90 \%$ of these patients will be untreated due to the several financial burdens [4,5]. Osteoporosis is characterized by low bone mass and bone microarchitecture deterioration due to the more rapid bone resorption process than bone formation, which usually leads to bone fragility and increased risks of fractures [6].

The most common available strategies used in preventing and treating osteoporosis are the use of agents that inhibit osteoclast activity hence bone resorption. The widely used antiresorptive agents are estrogen, selective estrogen receptor modulators (SERMs), bisphosphonates, and calcitonin. However, these agents cannot promote bone formation and are incapable of osteoporotic bone regeneration. Therefore, the inductive factors or osteoprogenitor cells during bone grafts are recently used to improve osteogenesis in osteoporosis $[7,8]$.

Glucocorticoids have a crucial role in the normal regulation of bone remodeling, but prolonged glucocorticoid overexposure causes osteoporosis. In vivo, glucocorticoids promote bone resorption by stimulating osteoclastogenesis and consequently decreasing bone formation. Even though glucocorticoids promote in vitro osteoblastic cell differentiation, they have important inhibitory actions on bone formation [9,10].

Bioceramics are a viable material with a large number of clinical uses which go from head to toe and include bones, joints, and teeth repairs. These repairs become necessary when the existing part becomes diseased, damaged, or simply wears out [11]. One of the bioceramic materials is hydroxyapatite (HA), which is a member of the apatite group of ceramics. Hydroxyapatite bioceramic $\left(\mathrm{Ca}_{10}\left(\mathrm{PO}_{4}\right)_{6}(\mathrm{OH})_{2}\right)$ with a hexagonal crystalline structure has been extensively studied due to its chemical similarity to the mineral component of bones.

The degree of crystallinity, crystallite size, processing condition (temperature, pressure, and partial water pressure), and porosity are considered as the factors affecting in vitro HA ionization and the dissolution rate [12]. HA has favorable biological properties that are proven in vitro and in vivo, which include biocompatibility, bioactivity, osteoconduction, osteointegration, and osteoinduction (in certain conditions) that resulted in rapid bone formation in a host body and strong biological fixation to bony tissues. Therefore, it represents a large number of regenerative graft materials are available in the market such as bone substitutes, metallic implants coat, tissue engineering scaffolds, and drug delivery carriers $[11,13]$. HA promoted the adhesion and osteogenic differentiation of cultured-osteoblast cells on their surface through Wnt/ $\beta$ - catenin signaling [14]. Wnt $/ \beta$-catenin signaling plays a critical role in the achievement of peak bone mass, affecting the commitment of mesenchymal progenitors to the osteoblast lineage and the anabolic capacity of osteoblasts depositing bone matrix [15].

Different forms of HA can be used for biomedical applications as porous and dense blocks, granules, paste, cement, nanorods, belts, and coatings [16]. The nano-rods HA are better than other forms because they not only reduce bone loss but also increase cortical bone thickness.

Various methods are used to synthesize nanostructure HA powder including spontaneous combustion method [17], precipitation method [18], electrochemical deposition [19], solgel processes [20], hydrothermal synthesis [21], and microwave irradiation synthesis [2,22]. 
Microwave irradiation is a mild, convenient, rapid, and efficient method to synthesize $\mathrm{HA}$, which results in the production of high-purity powder with small-narrow distributed particle sizes $[23,24]$.

Sintering is a process of consolidating a compacted powder by heat treatment at elevated temperatures, usually at $\mathrm{T}>0.5 \mathrm{Tm}[\mathrm{K}]$, where $(\mathrm{Tm})$ is the melting temperature of that specific material. The sintering process aims to produce advanced sintered ceramic with microstructural control which is a high relative density and homogeneous microstructure of small grains [25]. Nano-powders are typically pressed and sintered to produce dense nanostructured ceramic materials. The high sintering temperatures and long sintering times required for the consolidation of ceramic powders frequently result in extreme grain coarsening and decomposition of the ceramic, which is typical of conventional sintering methods and leads to the deterioration of the mechanical properties [26]. To overcome the problem of grain growth, unconventional sintering and densification techniques have been proposed.

The hybrid heating technique combines direct microwave heating with radiant heating. The hybrid heating system will heat the sample more readily at low temperatures providing a more uniform heating gradient by flattening out the inverted temperature profile inside the ceramic body [27].

Hybrid microwave heating technique achieved by microwave assist technology (MAT) ovens combines the microwave and conventional radiation to heat materials rapidly and evenly. The hybrid heating system will heat the sample more readily at lower temperatures providing a more uniform heating gradient by flattening out the inverted temperature profile within the ceramic body, thus inhibiting grain growth, reducing the time and energy required during this formation process and improving the mechanical properties [27,28].

The present study was attempted to synthesize hydroxyapatite nanorod powder by microwave irradiation method. Then, nanorod hydroxyapatite is sintered in two methods: conventional heating and hybrid microwave heating at a temperature of $1100{ }^{\circ} \mathrm{C}$ and at different times. The second aim was to investigate the effect of nanorod hydroxyapatite before and after conventional and microwave hybrid sintering process on osteoporosis induced by cortisone in osteoblastic cells isolated from rat bone marrow through the Wnt/ $\beta$-catenin signaling pathway.

\section{Materials and Methods}

\subsection{Materials}

Calcium nitrate tetrahydrate $\left(\mathrm{Ca}\left(\mathrm{NO}_{3}\right)_{2} \cdot 4 \mathrm{H}_{2} \mathrm{O}\right)$ was purchased from Winter Laboratory (WinLab), UK (assay 99\%-molar mass $236.15 \mathrm{~g} \cdot \mathrm{mol}^{-1}$ ). Ortho-phosphoric acid $\left(\mathrm{o}-\mathrm{H}_{3} \mathrm{PO}_{4}\right)$ was obtained from Sigma-Aldrich, St. Louis, MO, USA, (assay $\geq 85$ wt. \% in $\mathrm{H}_{2} \mathrm{O}-$ molar mass $\left.98 \mathrm{~g} \cdot \mathrm{mol}^{-1}\right)$. Sodium hydroxide $(\mathrm{NaOH})$ was purchased from Fluka, Switzerland (assay $97 \%$ - molar mass $40 \mathrm{~g} \cdot \mathrm{mol}^{-1}$ ), hydrocortisone $\left(\mathrm{C}_{21} \mathrm{H}_{30} \mathrm{O}_{5}\right)$ was obtained from Sigma-Aldrich, USA (assay $\geq 98 \%$ ). Collagenase NB 4 Standard Grade was purchased from SERVA, Heidelberg, Germany (activity: $\geq 0.10 \mathrm{U} / \mathrm{mg}$ ); ascorbic acid (Vitamin C) (USB Corporation Cleveland, St. Louis, MO, USA); minimum essential medium Eagle-alpha modification ( $\alpha$-MEM) Lonza, Belgium; Dulbecco's modified Eagle's medium, with $4.5 \mathrm{~g} / \mathrm{L}$ glucose and L-glutamine (DMEM) (Lonza, Bornem, Belgium); L-glutamine; penicillin 10,000 IU/mL and streptomycin 10,000 $\mu \mathrm{g} / \mathrm{mL}$ Lonza, Belgium fetal bovine serum (FBS) (heat-inactivated, EuroClone SpA, Pero, Italy); trypsin-EDTA solution containing $0.25 \%$ trypsin (Lonza, Belgium); dimethyl sulfoxide (DMSO) for freezing cells; 3-(4, 5-dimethylthiazol-2-yl)-2, 5-diphenyl tetrazolium bromide (MTT) obtained from BIO BASIC, Canada.

\subsection{Animal and Ethical Approval}

Male neonatal Wister albino rats (10 $\pm 5 \mathrm{~g}$, aged 0 to 5 days) were obtained from experimental animal house, Institute of Graduate Studies and Research-IGSR, Alexandria University. All animal procedures were performed in the animal house of Pharmaceutical 
and Fermentation Industry Development Center (PFIDC), City of Scientific Research \& Technological Applications (SRTA-city), New Borg El Arab, Alexandria.

This study design was approved by PFIDC institutional animal care and use committees (IACUSs) where the approval number was IACUC\#34-3C-0719.

\subsection{Synthesis of Nanorods HA Samples}

Nano-rods HA powder sample was prepared by microwave-irradiation method via a home model microwave [22,29]. Total of $100 \mathrm{~mL}$ of $\mathrm{H}_{3} \mathrm{PO}_{4}(0.1 \mathrm{M})$ solution was heated until $60{ }^{\circ} \mathrm{C}$ then a $100 \mathrm{~mL}$ of $\mathrm{Ca}\left(\mathrm{NO}_{3}\right)_{2} \cdot 4 \mathrm{H}_{2} \mathrm{O}(0.167 \mathrm{M})$ solution was added until the temperature reached $60{ }^{\circ} \mathrm{C}$ again. The $\mathrm{pH}$ of the mixture solution was adjusted to 11 with about $10 \mathrm{~mL}$ of $\mathrm{NaOH}(5 \mathrm{M})$ solution to obtain a homogeneous milky solution using magnetic stirring in all steps. After that, a $200 \mathrm{~mL}$ of homogeneous milky solution added in a $1000 \mathrm{~mL}$ beaker for every single preparation was heated in a $26 \mathrm{~L}$ home model microwave chamber $2.45 \mathrm{GHz}, 900 \mathrm{~W}$ (CA MW2626, CAIRA, Egypt) for $30 \mathrm{~min}$ until dehydration. Then, the precipitate was heated in a drying oven (Nabertherm controller B170, Germany) at $100{ }^{\circ} \mathrm{C}$ for $30 \mathrm{~min}$ until complete drying. The overall chemical reaction occurred as follows:

$10\left(\mathrm{Ca}\left(\mathrm{NO}_{3}\right)_{2} \cdot 4 \mathrm{H}_{2} \mathrm{O}\right)+6 \mathrm{H}_{3} \mathrm{PO}_{4}+20 \mathrm{NaOH} \rightarrow \mathrm{Ca}_{10}\left(\mathrm{PO}_{4}\right)_{6}(\mathrm{OH})_{2}(\downarrow)+20 \mathrm{NaNO}_{3}+58 \mathrm{H}_{2} \mathrm{O}$

The resulting white precipitate was washed with distilled water several times and then dried at $100{ }^{\circ} \mathrm{C}$ for $8 \mathrm{~h}$. The obtained HA powder was named HA green (HAg). The HA white powder was dry pressed with mold pressure $80 \mathrm{MPa}$ to form HA discs. HA discs were checked using a digital micrometer for a uniform thickness of $0.8 \mathrm{~mm}$ and a diameter of $1.0 \mathrm{~mm}$.

\subsection{Sintering of HA Discs}

Hydroxyapatite discs were sintered with two different techniques: conventional sintering and microwave hybrid sintering using a microwave assist technology (C-MAT) furnace (MRF 16/22 Carbolite, Derbyshire, UK). The prepared HA discs (two samples per firing cycle/method) were put in an Alundum ignition ceramic boat inside the C-MAT furnace cavity. The furnace temperature was raised by a heating rate of $5^{\circ} \mathrm{C} / \mathrm{min}$ until the target sintering temperatures reached $1100{ }^{\circ} \mathrm{C}$. For Conventional sintering: the temperatures were held for $1-2 \mathrm{~h}$ at $1100{ }^{\circ} \mathrm{C}$ and for Hybrid Microwave sintering: the microwave was switched on using $100 \% \mathrm{MW}$ power, then held for 20-30 min. Subsequently, the furnace was allowed to cool using furnace cooling fans to room temperature by the cooling rate. Each optimized sintered HA disc was checked using a digital micrometer to confirm the uniform shrinkage of samples [30,31].

\subsection{Characterization of HA Samples}

The green HA and HA sintered disc samples were coated with gold and investigated microscopically using scanning electron microscopy (SEM, JEOL JSM 6360LA, Tokyo, Japan) coupled with energy dispersive X-ray spectroscopy (EDX, Gatan, Pleasanton, CA, USA), for each HA sample $(n=3)$. The microscopic size of the HA green sample was characterized by transmission electron microscopy (TEM, JEOL 2100 PLUS, Tokyo, Japan). Thermal stability of the HA green sample was studied using a thermogravimetric analyzer (TGA-50, Shimadzu, Japan). The temperature program was raised from room temperature to $1200{ }^{\circ} \mathrm{C}$ with a heating rate of $10^{\circ} \mathrm{C} / \mathrm{min}$ under nitrogen flow rate of $20 \mathrm{~mL} / \mathrm{min}$ [32]. Fouriertransform infrared spectroscopy (FTIR-8400 S Shimadzu, Japan) was used to determine the functional groups of the HA samples. The recorded region is from $400-4000 \mathrm{~cm}^{-1}$ using the spectroscopic grade potassium bromide $(\mathrm{KBr})$ pellet technique. The crystal phases of the HA green and sintered samples will be obtained using an X-ray diffractometer (XRD—6100 Shimadzu, Japan), operating with $\mathrm{CuK} \alpha$ radiation $(\lambda=0.154060 \mathrm{~nm})$ generated at $30 \mathrm{kV}$ and $30 \mathrm{~mA}$, scans were performed at $2^{\circ} \mathrm{min}^{-1}$ for $2 \theta$ values between 20 and 60 degrees. XRD data were used to calculate crystallite size and crystallinity $[33,34]$. The mean crystallite 
size (D) of the particles in nm was calculated from the line broadening measurement of XRD reflection from Scherrer's equation [22]:

$$
\mathrm{D}(\mathrm{nm})=\frac{0.89 \lambda}{\beta \cos \theta}
$$

where: $\lambda=0.15405$ is the wavelength for $(\mathrm{CuK} \alpha), \beta$ the full width at half-maximum for the diffraction peak under consideration (rad), and $\theta$ is Bragg's diffraction angle $\left(^{\circ}\right)$. The diffraction peak at $2 \theta=26.04^{\circ}$ was chosen for the calculation of the crystallite size since it was much sharper and isolated from the others. This peak was assigned to $\left(\begin{array}{lll}0 & 0 & 2\end{array}\right)$ Miller's plane family and showed the crystal growth along the c-axis of the hydroxyapatite crystalline structure.

The degree of crystalline phase $\left(X_{\mathcal{c}}\right)$ of HA powders was evaluated by the following equation [35]:

$$
X_{\mathrm{c}}=\frac{1-V_{112 / 300}}{I_{300}}
$$

where: $I_{300}$ is the intensity of $(300)$ diffraction peak and $V_{112 / 300}$ is the intensity of the

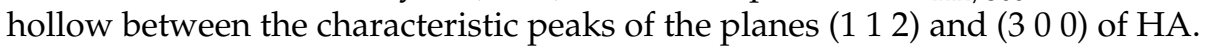

The mechanical testing of HA samples: For the determination of the surface roughness values, a portable surface roughness tester (Mitutoyo Surftest, SJ-201, Kawasaki, Japan) was used. It is a hand-held electronic instrument that measures the peak-to-valley height of the surface profile of cleaned and polished surfaces. Three discs were measured for each sintered samples to obtain the mean roughness value [36]. After completing the surface roughness testing, the same samples were used for determination of the hardness values. Hardness evaluation was conducted using Digital Microhardness Tester (Zwick/Roell, IDENTEC, ZHV $\mu$-S, West Midlands, England), by applying a load of $50 \mathrm{~g}$ and $500 \mathrm{~g}$ (for $\mathrm{HAg}$ and HA different sintered discs, respectively) for $10 \mathrm{~s}$. Each sample was positioned in a manner that the device's indenter tip was perpendicular to the sample surface to be tested. The average of the five indentations was then calculated for each sample. The mean of the three examined samples for each sintered discs was taken as the hardness of the material [37].

\subsection{Isolation of Osteoblast Cells and Induction of Osteoclast Cell Formation}

Rat calvarial osteoblast (RCO) cultures were used as a model to assess osteoblast behavior and differentiation. Cells were isolated from 0 to 5 days old neonatal male Wister albino rats. Parietal and occipital bones were dissected and washed with phosphate-buffered saline (PBS). The harvest bones were minced and subsequently digested by incubating in 700 units $/ \mathrm{mL}$ of type 1 collagenase at $37^{\circ} \mathrm{C}$. The supernatant of the first digestion was discarded and the calvarial fragments were treated five times with collagenase ( $20 \mathrm{~min}$ at $37^{\circ} \mathrm{C}$ ) and the subsequent supernatants were collected, combined, and sedimented. The resulting cell pellet was re-suspended and cultured in cultured media (CM) $\alpha$-MEM supplemented with $10 \%(v / v)$ fetal bovine serum (FBS), and antibiotics $(200 \mathrm{U} / \mathrm{mL}$ penicillin and $200 \mu \mathrm{g} / \mathrm{mL}$ streptomycin). RCO cultures were maintained in a humidified $5 \% \mathrm{CO}_{2}$ atmosphere at $37^{\circ} \mathrm{C}[38]$.

\subsection{Induction of Osteoclast Cell Formation (Induction of Osteoporosis)}

Induction of osteoporosis using glucocorticoids was carried out according to the protocols of Ishida and Heersche (1998) and Weinstein (2012) with some modifications [10,39]. Osteoblastic cells were plated into six-well sterile culture plates at $10^{5}$ cells/well and incubated in CM until a confluent layer was achieved. To determine the dose of cortisol used in this experiment, osteoblastic cells were plated in sterile six-well culture plates at $10^{5}$ cells / well incubated in CM until a confluent layer was achieved and a series concentration of hydrocortisone $(0,0.125,0.25,0.5,1,2 \mathrm{mg} / \mathrm{mL})$ was added. The plate was incubated for 21 days, then the concentration of Tartrate-resistant acid phosphatase (TRAcP) was measured in each well, and it was found that TRAcP was increased in constant value 
in a concentration of $0.5-2 \mathrm{mg} / \mathrm{mL}$, therefore we chose $0.5 \mathrm{mg} / \mathrm{mL}$ cortisone to induced osteoclast formation. To a confluent layer of osteoblast cells, $0.5 \mathrm{mg} / \mathrm{mL}$ cortisone was added and every 3-4 days the media was changed. After 21 days, the existence of osteoclast cells was assessed by $10 \%$ alizarin red $S$ stain.

\subsection{Culture of Osteoblast (OB) and Osteoclast (OC) on HA Discs}

The osteoblast or osteoclast cells were cultured on six-well sterile culture plates at a concentration of $1 \times 10^{5}$ cells/well. Cells were allowed to grow in complete media (10\% FBS, $2 \mathrm{mM}$ L-glutamine in $\alpha$-MEM) for 2 days to reach $70 \%$ confluence. Thereafter, the spent media were removed and replaced with fresh media ( $2 \mathrm{~mL}$ of $\alpha$-MEM) containing $6.8 \mathrm{mg}$ different HA discs (HAg, HA1h, HA2h, HA20m, and HA30m), each HA disc cleaned in an ultrasonication bath and autoclaved before using). Cells were incubated at $37{ }^{\circ} \mathrm{C}$, $5 \% \mathrm{CO}_{2}$ for 7 days. The adherent cells were enzymatically detached with trypsin/EDTA solution (1X) and then the suspended cells were collected by centrifugation at $400 \times g$ for $5 \mathrm{~min}$. The cell pellets were washed three times with phosphate buffer saline (PBS). Then, cells were resuspended in PBS ( $\mathrm{pH}$ 7.4) containing protease inhibitor and subjected to ultrasonication three times. The supernatant was collected for quantification of biochemical parameters $[40,41]$.

\subsection{Cell Viability and Proliferation Test}

Different HA samples $(6.8 \mathrm{mg} / \mathrm{mL})$ were plated in a 96-well cell culture plate with $200 \mu \mathrm{L}$ of the cultured medium that contained 100,000 osteoblasts or osteoclast/well in DMEM medium followed by plate incubation for 7 days in $\mathrm{CO}_{2}$ incubator $\left(37^{\circ} \mathrm{C}, 5 \% \mathrm{CO}_{2}\right.$, and $90 \%$ relative humidity). At the end of the treatment period, MTT was first prepared as a stock solution of $5 \mathrm{mg} / \mathrm{mL}$ in phosphate buffer saline PBS ( $\mathrm{pH}$ 7.2) and filtered. Then, $20 \mu \mathrm{L}$ of MTT solution was added to each well and the plate was incubated for $4 \mathrm{~h}$ in a $\mathrm{CO}_{2}$ incubator. After incubation, the plate was centrifuged at $1650 \mathrm{rpm}$ for $10 \mathrm{~min}$ and the medium was discarded. The formazan crystals (MTT byproduct) were re-suspended in $100 \mu \mathrm{L}$ DMSO and reading was measured at a wavelength of $570 \mathrm{~nm}$ [42].

The $\%$ viability was calculated as follows: (AT/AC) $\times 100$.

$\mathrm{AT}=$ mean absorbance of cells treated with different HA samples.

$\mathrm{AC}=$ mean absorbance of control untreated cells with culture medium only.

\subsection{Mineralization Detection}

Alizarin red S staining was used to evaluate the successful isolation of osteoblast cells and in vitro bone-formation which produced calcium-rich deposits. The cells were carefully washed with PBS, pH 7.4. After PBS aspiration, cells were fixed in neutral buffered formalin $(10 \%)$ and incubated for $30 \mathrm{~min}$. After formalin solution removal, enough alizarin red $\mathrm{S}$ staining solution (1\%, pH 4.1-4.3) was added to cover the cell monolayer and the plate was incubated at room temperature in the dark for $45 \mathrm{~min}$. Carefully, alizarin red S staining solution was aspirated and the cell monolayer was washed four times with distilled water. Cells were examined under the inverted microscope with $400 \times$ magnification. Calcium deposits were stained bright orange-red [43].

\subsection{Bone Remodeling Biomarkers}

Proliferation markers such as osteocalcin, alkaline phosphatase (ALP), and extracellular calcium concentration were assayed using commercial kits supplied from Nordic Bioscience Diagnostics (Herlev, Denmark), Biosystems (Barcelona, Spain), and Sigma- Aldrich (St. Louis, MO, USA), respectively, while Tartrate-resistant acid phosphatase (TRAcP) as a marker of bone resorption was assayed according to Takara Bio Inc. (Kusatsu, Japan).

\subsection{Molecular Investigations}

The levels of CD105, $\beta$-catenin, GSK3 $\beta$, and GSK3 $\beta$ pS9 were measured by manual quantitative ELISA technique using rabbit polyclonal CD105 (\# PA5-80582, Invitrogen, 
Waltham, MA, USA), rabbit monoclonal $\beta$-catenin, and GSK3 $\beta$ (\#8480 and \#9315, respectively, Cell Signaling Technology, Danvers, MA, USA) as well as rabbit polyclonal GSK3 $\beta$ pS9 (\#abx328236, abbexa, Shanghai, China). The antigen was diluted to a final concentration of $100 \mu \mathrm{g}$ protein in a coating buffer (bicarbonate/carbonate, $0.2 \mathrm{M}, \mathrm{pH} 9.6$ ) in wells of polyvinyl chloride (PVC) microtiter plate. Samples were loaded in duplicate and incubated overnight at $4{ }^{\circ} \mathrm{C}$. The remaining protein binding sites in the coated wells were blocked using blocking solution (bovine serum albumin (BSA), 5\%). To reduce the non-specific binding, primary and secondary antibodies were diluted in the blocking solution. After incubation with primary and secondary antibodies (Goat anti-rabbit IgG, ALP, \#A8025, Sigma-Aldrich, USA), substrate solution ( $\rho$-nitrophenyl phosphate, disodium salt, PNPP) was added. The reaction was stopped using sodium hydroxide ( $3 \mathrm{M})$ and the color developed was read at $450 \mathrm{~nm}$ on a plate reader (Sanofi Diagnostics Pasteur, Lyon, France). Standard curves for each protein were constructed [44]. Determination of CD90, PARR-y, and p38-MAPK proteins levels were determined using an ELISA kit according to manufactures' instructions. The concentration of GSK3 $\beta$ and GSK3 $\beta$ pS9 were expressed in the $\mu \mathrm{g} / \mathrm{mg}$ protein while $\mathrm{p} 38 \mathrm{MAPK}, \mathrm{CD} 90$, and CD105 concentrations were expressed in $\mathrm{ng} / \mathrm{mg}$ protein and PARR- $\gamma$, and $\beta$-catenin concentrations were expressed in the $\mathrm{pg} / \mathrm{mg}$ protein.

\subsection{Statistical Analysis}

Data were analyzed by one-way analysis of variance (ANOVA) using Primer of Biostatistics (Version 5) software program using SPSS Statistics (StatSoft, Tulsa, OK, USA). The significance of means \pm SD was detected groups by the Student-Newman-Keuls comparison test at $p<0.05$.

\section{Results and Discussion}

\subsection{Chemical Analysis of Hydroxyapatite Samples}

\subsubsection{X-ray Diffraction (XRD) Analysis}

The XRD pattern of the HA powder prepared by the microwave irradiation method (HAg) shows that all the peaks were indexed according to the hexagonal phase of hydroxyapatite and the standard XRD card (ICDD No. 01-074-0565) as displayed in Figure 1a. While Figure $1 \mathrm{~b}$ shows the effect of different sintering temperatures/time on the prepared hydroxyapatite, the diffraction peaks of sintered samples were narrow and well separated and had the highest intensity when compared to the broad diffraction peaks of the green HA sample. The position and FWHM (full width at half-maximum) of the (002) reflection peak were used for the calculation of crystal size and crystallinity index. Table 1 shows that we succeed in producing $\approx 35 \mathrm{~nm}$ crystal-sized pure hydroxyapatite nanorods-like particles with a high degree of crystallinity and no impurities as required for biomedical application. The sintering time in both sintering techniques (conventional and hybrid microwave sintering) had an increasing effect on hydroxyapatite average crystallite size and HA crystallinity index. In contrast, HA samples sintered by hybrid microwave heating showed an increase in the intensity of peaks than that of the samples sintered by conventional heating. Furthermore, the intensity of this peak increased when the time of sintering was increased. Based on the XRD measurements, no impurity peaks such as calcium oxide $(\mathrm{CaO})$ or $\beta$-TCP were detected in the diffraction pattern before and after the heat treatment process. This indicates that all HA samples were phase-purified and that both used sintering methods did not cause hydroxyapatite decomposition. Therefore, it is acceptable to use our HA samples as biomaterials in biomedical applications [33,45]. 


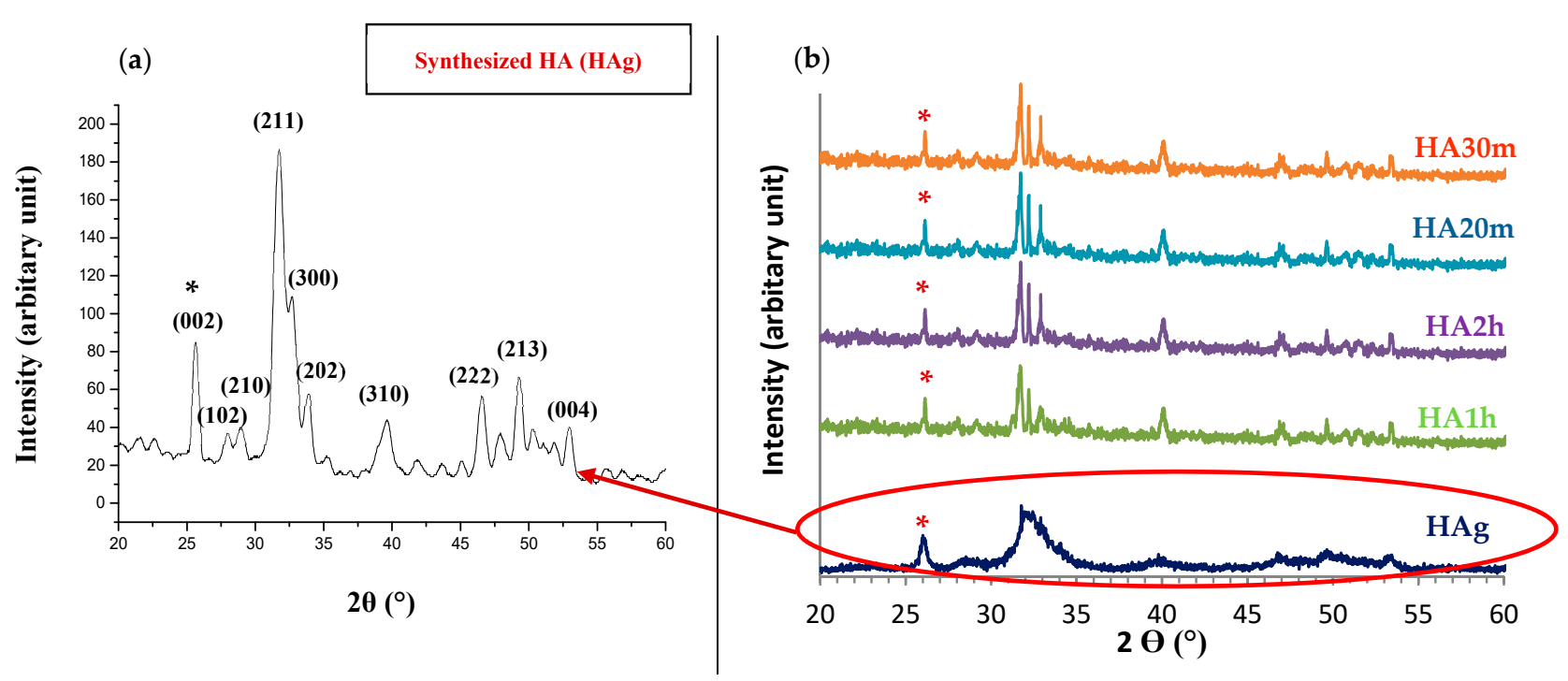

Figure 1. X-ray diffraction pattern of the hydroxyapatite samples: (a) XRD spectra of hydroxyapatite nanoparticles (HA green) sample (b) HA green, HA microwave hybrid sintered at $1100{ }^{\circ} \mathrm{C}$ for $20 \mathrm{~min}(\mathrm{HA} 20 \mathrm{~m})$ and $30 \mathrm{~min}(\mathrm{HA} 30 \mathrm{~m})$ and $\mathrm{HA}$ conventional sintered at $1100{ }^{\circ} \mathrm{C}$ for $1 \mathrm{~h}(\mathrm{HA} 1 \mathrm{~h})$ and $2 \mathrm{~h}(\mathrm{HA} 2 \mathrm{~h})$, respectively. $\left({ }^{*}\right)$ the (002) reflection peak.

Table 1. Average crystallite size and crystallinity of hydroxyapatite.

\begin{tabular}{cccc}
\hline Sample & Sintering Time & $\begin{array}{c}\text { Average Crystallite } \\
\text { Size (nm) }\end{array}$ & $\begin{array}{c}\text { Average } \\
\text { Crystallinity (\%) }\end{array}$ \\
\hline HAg & - & 34.9 & 75.09 \\
HA1h & $1 \mathrm{~h}$ & 45.7 & 87.31 \\
HA2h & $2 \mathrm{~h}$ & 45.6 & 86.69 \\
HA20m & $20 \mathrm{~min}$ & 37.9 & 85.87 \\
HA30m & $30 \mathrm{~min}$ & 39.1 & 88.72 \\
\hline
\end{tabular}

\subsubsection{Fourier Transform Infrared Spectra of HA Powder}

Figure 2 shows the FTIR spectrum of precipitated HA powder before and after heat treatments. Figure 2a shows the typical absorption bands for $\mathrm{PO}_{4}{ }^{3-}$ at $559.3-560 \mathrm{~cm}^{-1}$, $878 \mathrm{~cm}^{-1}$, and 1040 and $1196 \mathrm{~cm}^{-1}$ [46]. There was a broadband of $\mathrm{H}_{2} \mathrm{O}$ at $1768 \mathrm{~cm}^{-1}$. Likewise, there was a band at $636 \mathrm{~cm}^{-1}$ and an extended vibration of the ions around $3578 \mathrm{~cm}^{-1}$ due to hydrogen-bonded $(\mathrm{OH}-)$ and a typical $\mathrm{C}=\mathrm{O}$ band at $1653 \mathrm{~cm}^{-1}$. These were the characteristic absorption bands of pure hydroxyapatite powders $[47,48]$.

Effects of sintering temperatures on the FTIR spectra of prepared hydroxyapatite samples: The typical property of $\mathrm{PO}_{4}{ }^{3-}$ bands of apatite structure at (559 and $1040 \mathrm{~cm}^{-1}$ ) was identified in all HA sintered samples. In addition, the peak of the $\mathrm{PO}_{4}{ }^{3-}$ band in $876 \mathrm{~cm}^{-1}$ gradually decreased in intensity and sharpened the band with increasing heat treatment time. While the $\mathrm{PO}_{4}{ }^{3-}$ band at $636 \mathrm{~cm}^{-1}$ appeared in the HAg sample only and disappeared in all sintered samples. In contrast, the intensity of the ion stretching band around $3578 \mathrm{~cm}^{-1}$ for hydrogen-bonded (OH-) gradually decreased with increasing sintering time as this band is very "sensitive" to temperature changes. All peaks were more involved in the conventional sintered and hybrid microwave samples than that in the green hydroxyapatite sample (HAg). The peak of the $\mathrm{C}=\mathrm{O}$ band at $1638 \mathrm{~cm}^{-1}$ decreased significantly with increasing sintering temperatures. These results are in agreement with the previous work of A. Rapacz-Kmita, et al. 2005, which proves that dehydroxylation of hydroxyapatite that occurs at conventional sintering was more than that of hybrid microwave sintering [47]. 
(a)

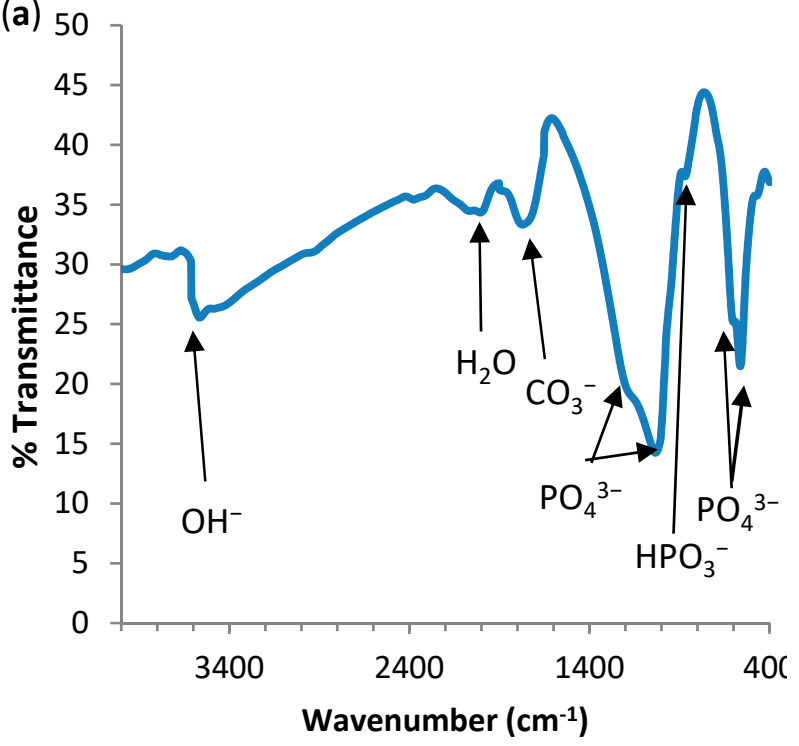

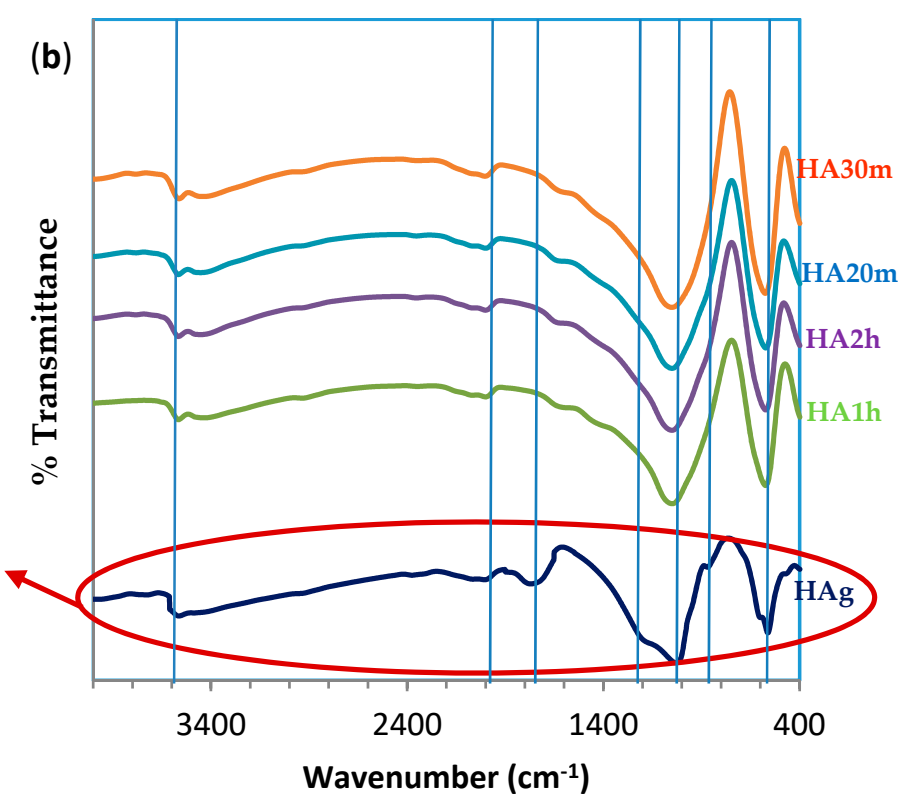

Figure 2. FTIR spectra of hydroxyapatite: (a) Hydroxyapatite green sample, (b) HA green, HA conventional sintered at $1100{ }^{\circ} \mathrm{C}$ for $1 \mathrm{~h}(\mathrm{HA} 1 \mathrm{~h})$ and $2 \mathrm{~h}(\mathrm{HA} 2 \mathrm{~h})$, respectively, and HA microwave hybrid sintered at $1100{ }^{\circ} \mathrm{C}$ for $20 \mathrm{~min}(\mathrm{HA} 20 \mathrm{~m})$ and $30 \mathrm{~min}(\mathrm{HA} 30 \mathrm{~m})$ respectively.

\subsubsection{Thermal Stability Analysis of HA Powder}

The TGA thermogram of green HA powder obtained by microwave irradiation method in the temperature range of $20-1200^{\circ} \mathrm{C}$ as demonstrated in Figure 3 . The weight loss diagram plotted a characteristic region at $22.95-182.38^{\circ} \mathrm{C}$, and the weight loss was about $0.425 \mathrm{mg}(8.01 \%)$ which was attributed to moisture vaporization (liberation of chemically bonded water). There was no significant weight loss in the range of $500-1200{ }^{\circ} \mathrm{C}$ where a stable curve was noticed within this temperature range, which confirms that the prepared HAg samples were thermally stable at high temperatures [32]. Thus, the prepared HA is a good material for sintering at high-temperature $1100^{\circ} \mathrm{C}$ and suitable for pharmaceutical and biomedical processing at $37^{\circ} \mathrm{C}$.

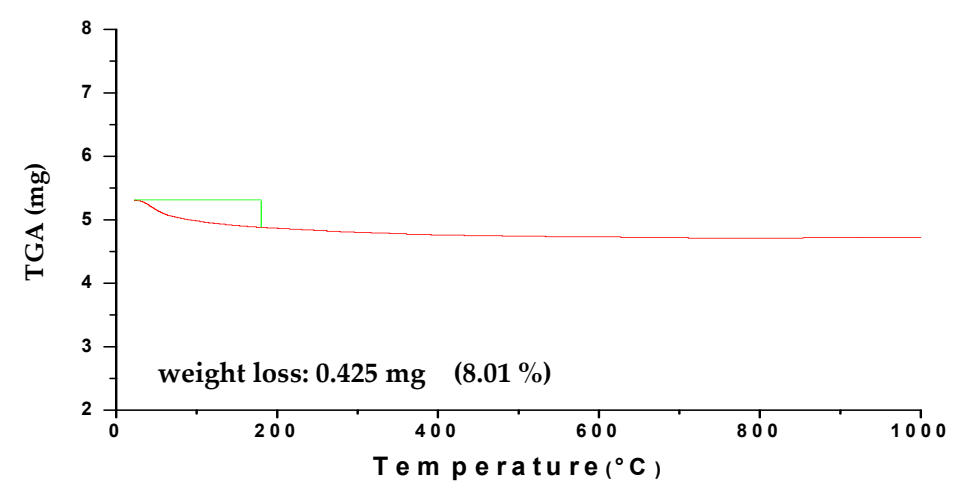

Figure 3. Thermal analysis pattern of green HA powder.

\subsubsection{Microstructure of HA Powder Using Transmission Electron Microscope}

TEM micrograph and the selected area electron diffraction (SAED) pattern of HA green particles are shown in Figure $4 \mathrm{a}-\mathrm{c}$ respectively. It is observed that green HA was a rodshaped morphology and smooth agglomerates of the crystal are also displayed in Figure 4a. The crystallite size of HAg is estimated from TEM images by image analysis freely available ImageJ software (ImageJA, GitHub, San Francisco, CA, USA) and the estimated average crystallite dimension was $13.67 \pm 5 \mathrm{~nm}$ width and $102.05 \pm 10 \mathrm{~nm}$ height (mean $\pm \mathrm{SD}$ ) as 
demonstrated in Figure 4b. The SAED pattern in Figure 4c confirms that the crystalline structure of HA was hexagonal and this is compatible with our XRD results [32,37].

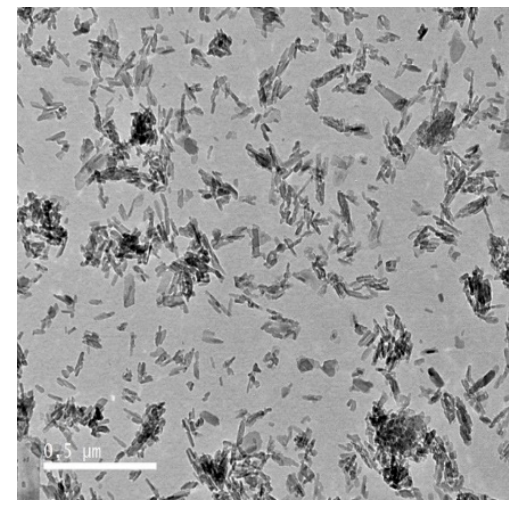

(a)

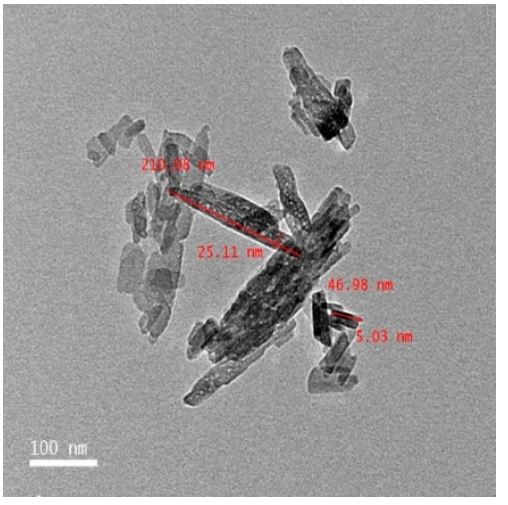

(b)

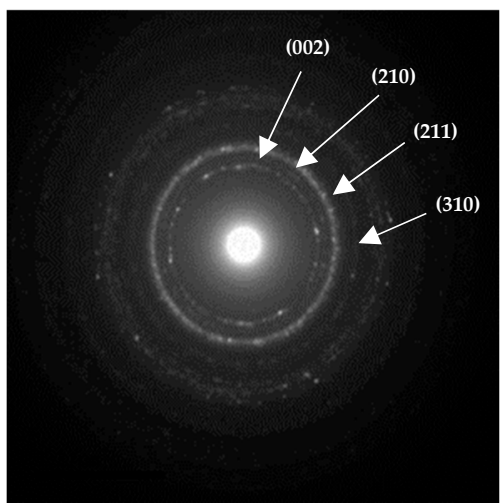

(c)

Figure 4. Transmission electron microscope $(\mathbf{a}, \mathbf{b})$ TEM micrograph of nanorods HA particles at different fields, showing HA nano rod-like particles, and (c) SAED pattern.

\subsubsection{Scanning Electronic Micrograph of HA Powder}

The morphological study of HA particles was studied using scanning electron microscope (SEM) as shown in Figure 5. The HA powder appeared agglomerated and consisted of a large number of fine HA particles with a relatively large pore size as shown in Figure 5a. The effects of sintering temperatures on the morphological features of prepared HA samples were characterized with sintering time variations of each sintering technique at 20,000 $\times$ and 30,000 $\times$ magnification. However, there was a significant increase in particle size of sintered conventional HA samples as compared to the sintered HAg and microwave samples. While there was uniform grain growth along with decreased porosity and clear grain boundaries in the microwave sintered samples. In general, this increase in particle size may be due to the augmentation of the coalescence of particles in conventional sintering. Whereas in the hybrid microwave sintering, the grain size was decreased and almost all sample porosity removed, which indicates that almost full-density HA was produced from both sintering techniques. These results were also found by S. Aarthy et al. [49].

\subsubsection{The Elemental Compositions of HA Powder}

Elemental analysis technology was performed to determine the elemental composition of HA samples. In this study, we evaluated the $\mathrm{Ca} / \mathrm{P}$ concentration ratio of different $\mathrm{HA}$ samples using SEM/EDX. EDX is a sensitive qualitative and semi quantitative analytical technique on the other hand EDX may be a destructive analysis in many cases. In general, the analytical resolution depends on the incident beam energy, the critical excitation energy for the X-rays of interest, the atomic weight, the atomic number, and the density of the sample which are mentioned in details in the ISO standard "ISO 22309:2011 Microbeam analysis-Quantitative analysis using energy-dispersive spectrometry (EDS) for elements with an atomic number of $11(\mathrm{Na})$ or above".

The standard EDX spectra recorded on the examined HA is shown in Table 2. The presented data show that the $\mathrm{Ca} / \mathrm{P}$ atomic ratio of the prepared $\mathrm{HA}$ was 1.658. The effect of sintering temperature and time on nano-hydroxyapatite samples was recorded using EDX spectra. In general, by increasing the sintered time, the $\mathrm{Ca} / \mathrm{P}$ atomic ratio was increased until reaching the stoichiometric value of $(\approx 1.67)$ in microwave hybrid sintered samples (HA20m and HA30m). Comparatively, the atomic $\mathrm{Ca} / \mathrm{P}$ ratio (1.70) of HA2h was the highest. Based on these results and SEM images, it is hypothesized that this increase in the atomic ratio in conventional and microwave hybrid sintering may be due to the coalescence of these particles occurring in three successive steps, approximation of particles, 
the formation of necks at particles contacts, and the coalescence of these particles. This has been previously demonstrated by S. Raynaud, et al. and J.K. Abifarin et al. [50,51].

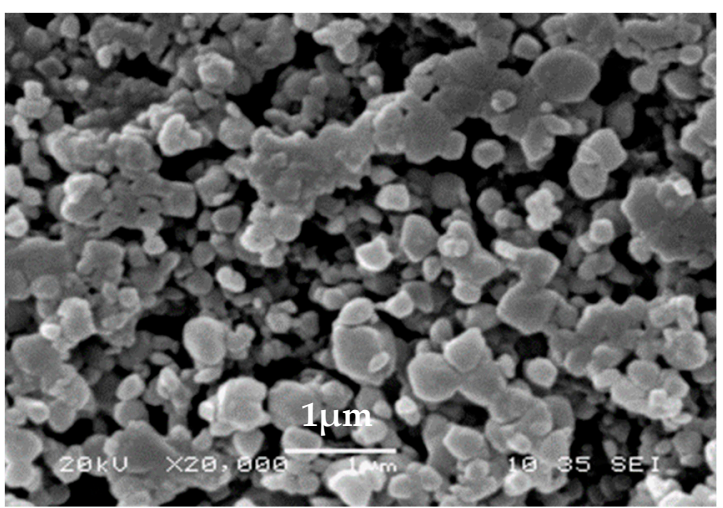

(a)

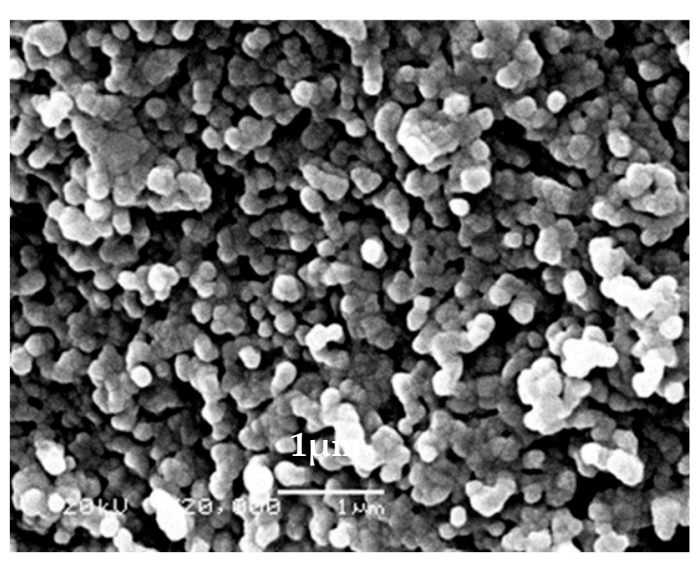

(b)

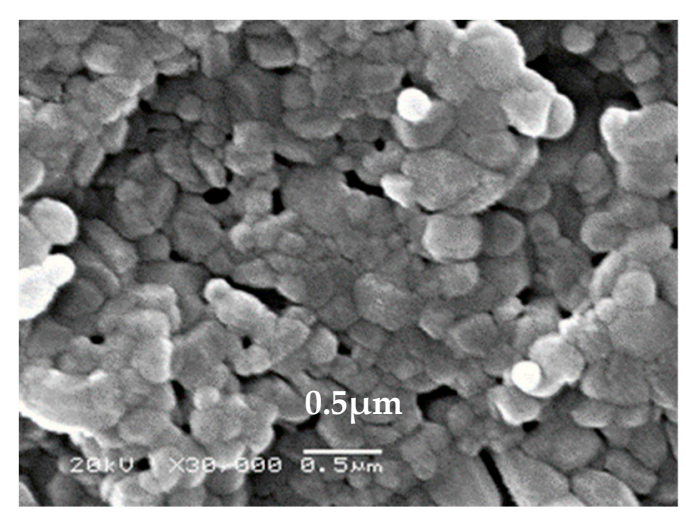

(d)

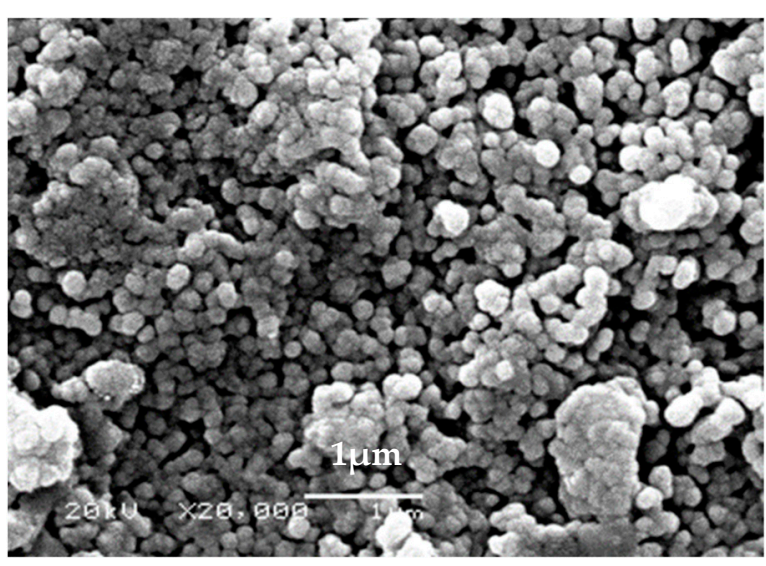

(c)

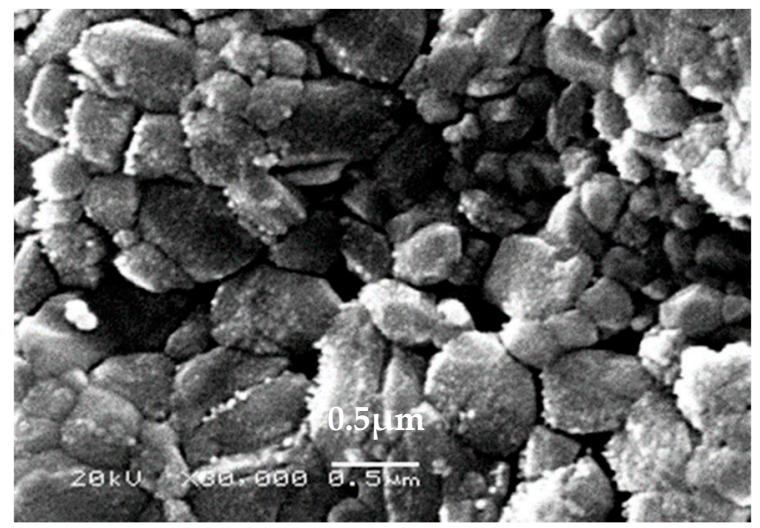

(e)

Figure 5. Morphology of hydroxyapatite (a) HAg: HA green without heat treatment, $(\mathbf{b}, \mathbf{c})$ HA microwave hybrid sintered at $1100{ }^{\circ} \mathrm{C}$ for $20 \mathrm{~min}(\mathrm{HA} 20 \mathrm{~m})$ and $30 \mathrm{~min}(\mathrm{HA} 30 \mathrm{~m})$ respectively. And (d,e) HA conventional sintered for $1 \mathrm{~h}$ (HA1h) and $2 \mathrm{~h}$ (HA2h) respectively. 
Table 2. Elemental composition of the sintered hydroxyapatite samples.

\begin{tabular}{ccccccc}
\hline \multirow{2}{*}{ Sample } & \multirow{2}{*}{ Sintering Time } & \multicolumn{5}{c}{ Elements/At (\%) } \\
\cline { 3 - 6 } & & $\mathbf{O}$ & Ca & P & C & Ca/P Ratio \\
\hline HAg & - & $56.92 \pm 0.3$ & $24.79 \pm 0.1$ & $14.95 \pm 0.5$ & $3.34 \pm 0.2$ & 1.658 \\
HA1h & $1 \mathrm{~h}$ & $50.80 \pm 0.1$ & $23.35 \pm 0.1$ & $14.02 \pm 0.5$ & $11.83 \pm 0.1$ & 1.665 \\
HA2h & $2 \mathrm{~h}$ & $50.40 \pm 0.5$ & $23.82 \pm 0.3$ & $14.00 \pm 0.6$ & $11.78 \pm 0.2$ & 1.701 \\
HA20m & $20 \mathrm{~min}$ & $50.90 \pm 0.7$ & $24.43 \pm 0.1$ & $14.60 \pm 0.3$ & $10.07 \pm 0.1$ & 1.673 \\
HA30m & $30 \mathrm{~min}$ & $47.69 \pm 0.2$ & $23.34 \pm 0.2$ & $13.91 \pm 0.7$ & $15.06 \pm 0.3$ & 1.678 \\
\hline
\end{tabular}

Results are the means \pm SD in each sample.

\subsubsection{The Mechanical Properties of HA Discs}

The influence of sintering temperature and time on the surface roughness and Vickers hardness of HA discs before and after sintered by conventional and microwave techniques are shown in Table 3. The values of surface roughness of HA discs ranged between 0.87 and $1.89 \mu \mathrm{m}$. The HAg showed the highest surface roughness $(1.89 \mu \mathrm{m})$. The surface roughness was decreased with the increase in the sintering time in both sintering techniques at $1100{ }^{\circ} \mathrm{C}$. In the literature, Deligianni et. al. 2000 reported a roughness value of HA ranging between 0.73 and $4.68 \mu \mathrm{m}$ and they showed that the roughness obtained on the HA surface had macroscopically parallel grooves and ridges. Thus, elongated cells (like osteoblast cells) orientated along grooves even on the smoother surfaces (low surface roughness) [36].

Table 3. Statistical analysis of surface roughness $(\mu \mathrm{m})$ and Vickers microhardness (HV and GPa) of HA samples.

\begin{tabular}{ccccc}
\hline Sample & Sintering Time & $\begin{array}{c}\text { Surface } \\
\text { Roughness } \mathbf{R}_{\mathbf{a}} \\
(\boldsymbol{\mu \mathbf { m } )}\end{array}$ & $\begin{array}{c}\text { Vickers Microhardness } \\
(\mathbf{H V})\end{array}$ & $\mathbf{( G P a )}$ \\
\hline $\mathrm{HAg}$ & - & $1.89 \pm 0.1$ & $16 \pm 0.2$ & $0.16 \pm 0.1$ \\
$\mathrm{HA1h}$ & $1 \mathrm{~h}$ & $0.98 \pm 0.1$ & $229 \pm 2.9$ & $2.25 \pm 0.2$ \\
HA2h & $2 \mathrm{~h}$ & $0.87 \pm 0.1$ & $263 \pm 3.8$ & $2.58 \pm 0.3$ \\
HA20m & $20 \mathrm{~min}$ & $1.69 \pm 0.2$ & $104 \pm 4.3$ & $1.02 \pm 0.1$ \\
HA30m & $30 \mathrm{~min}$ & $1.67 \pm 0.1$ & $135 \pm 5.6$ & $1.32 \pm 0.1$ \\
\hline
\end{tabular}

Results are the means \pm SD in each sample.

The mean Vickers microhardness of the green HA discs was 16 HV (0.16 GPa). These results are in agreement with that reported by Yudyanto et al. 2019 who stated that the hardness of the prepared HA was $10 \mathrm{HV}$ and the differences in the microhardness may be due to the different preparation methods [52]. Considering different HA sintering techniques, the linear increase of the Vickers microhardness with increasing sintering time was noted. The maximum of $263 \mathrm{HV}(2.58 \mathrm{GPa})$ was achieved at the conventional sintered HA2h sample. This result was in agreement with the findings of Curran et al. 2011 who reported that the hardness of their conventional and microwave sintered HA increased with increasing grain size [53,54].

\subsection{Effect of HA on Osteoporotic Bone Regeneration}

Figure 6 shows that osteoblast cells (with extracellular calcium deposits) were bright reddish while the osteoclast cells had no color (without extracellular calcium deposits) after 21 days of culture. Furthermore, it is noted that the osteoblast cells had oblong trapezoid-shaped morphology displaying positive staining for calcium deposition. While the osteoclast cells were larger, multinucleated, and appeared as a cluster. These results indicate the success of the isolation of osteoblast cells from the long bone of rats by type 1 collagenase digestion as well as the addition of hydrocortisone-induced osteoblast cells death and osteoclast cells formation $[55,56]$. 


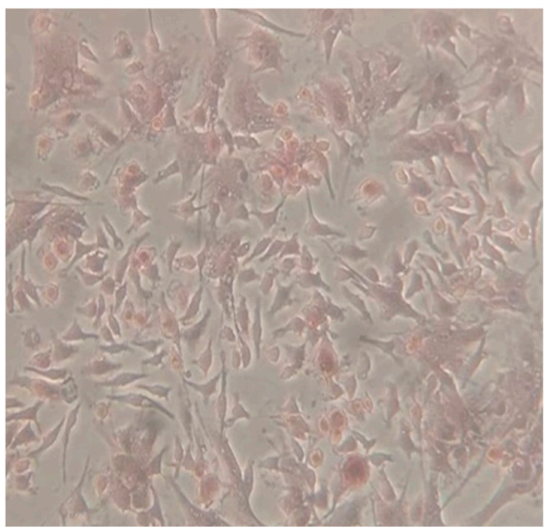

(a)

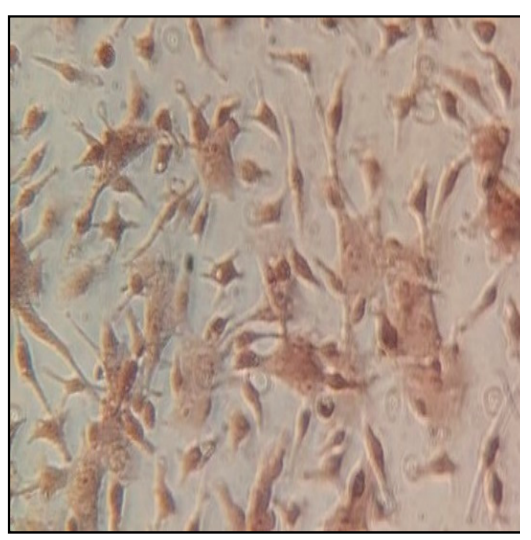

(b)

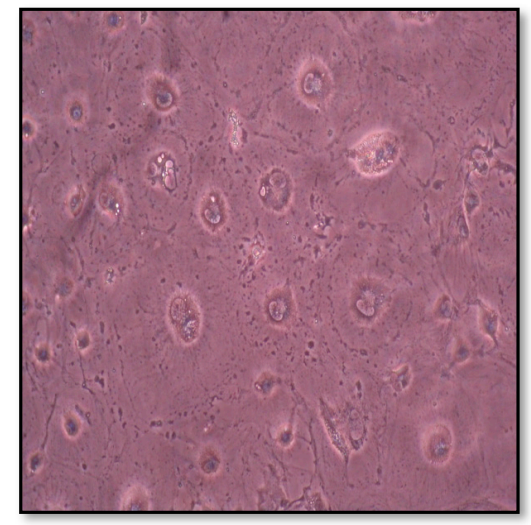

(c)

Figure 6. Inverted microscopy of alizarin red S-stained osteoblastic cells: Cells at day 21 of culture, $(\mathbf{a}, \mathbf{b})$ the differentiated osteoblasts cells show vast extracellular calcium deposits, stained in bright reddish and the oblong trapezoid-shaped morphology of the osteoblast cells with $200 \times$ and $400 \times$ magnifications respectively; (c) osteoclast cells (without extracellular calcium deposits) larger, multinucleated cells seen in a cluster rather than singly with $400 \times$ magnification.

\subsubsection{Effect of HA Treatment on Biological Characteristics of Osteoblast and Osteoclast Cells}

Figure 7 shows the effect of hydroxyapatite disc treatment on bone formation markers (osteocalcin and ALP), extracellular calcium concentration, bone resorption marker (TRAP), and cell viability, respectively. As demonstrated in Figure 7a, concerning the control (OB cells) group that showed the lowest osteocalcin level, treatment with cortisol for 21 days (OC cells) increased the osteocalcin to its maximum obtained value, at $p>0.05$. Although all OB treatments increased the osteocalcin levels, they decreased OC osteocalcin levels, at $p<0.05$.

Treatment of osteoblast with HAg and HA30m decreased the ALP activity while the treatment with HA1h did not affect the enzyme activity and finally, the treatment of OB with HA20m and HA2h increased the enzyme activity when compared to OB level, at $p<0.05$. Where OB treated with HA20m showed the highest ALP activity, at $p<0.05$. For osteoclast cells that showed the lowest ALP activity, all treatments with different HA discs increased ALP activity to lower levels than that of OB except the treatment with HA g that showed OC activity, at $p<0.05$ as shown in Figure $7 \mathrm{~b}$.

OC cells showed the lowest calcium concentration, $p<0.05$. Treatment of OB or OC cells with different HA discs had a significantly increased calcium level higher than that of the OB cells, and these positive increments in all treated cells were significantly similar, at $p<0.05$ (Figure 7c). Treatment of OB cells with HA20m, HA1h, and HA2h significantly increased TRAPc activities than that of control (OB) cells, while the other treatment showed the same control OB level, at $p<0.05$. In the case of OC cells which showed the highest TRAP level, addition of HA different discs significantly decreased TRAP levels but failed to normalize them at $p<0.05$. Among the OC-treated groups, the lowest level appeared in the case of HA30m disc at $p<0.05$ (Figure 7d). Finally, Figure 7e showed that the OB and OC cells were seeded on the HA scaffolds surface and cultured for seven days, then a viability test was performed. Treatment of OB cells with different HA discs significantly decreased cell viability than that of control (OB) cells at $p<0.05$. In the case of OC cells, cell treatment with HAg decreased cell viability while treatment with HA1h and HA2h increased it, and finally the treatment with HA20m or HA30m did not affect the proportion of cell viability at $p<0.05$. 


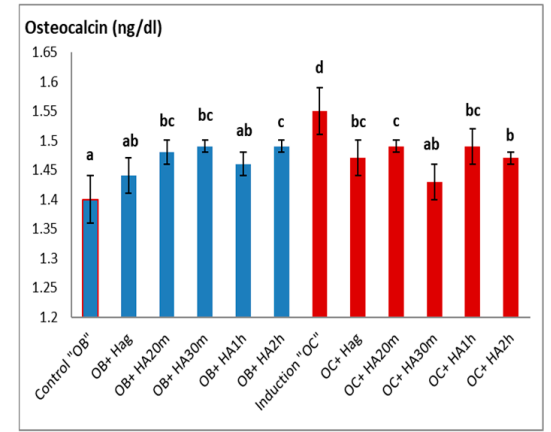

(a)

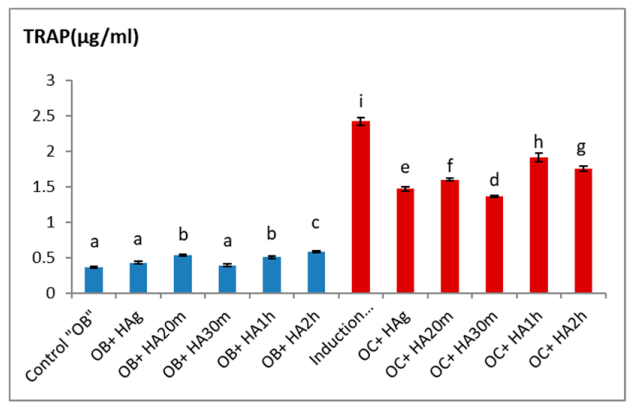

(d)

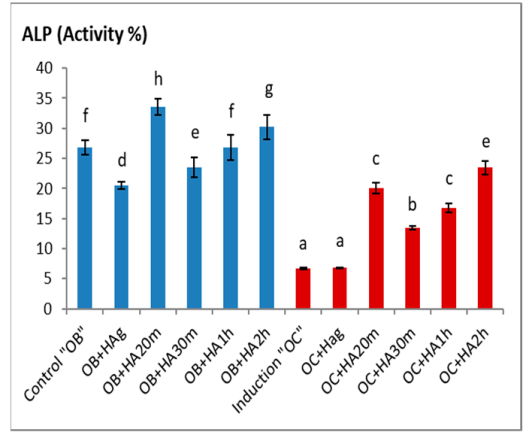

(b)

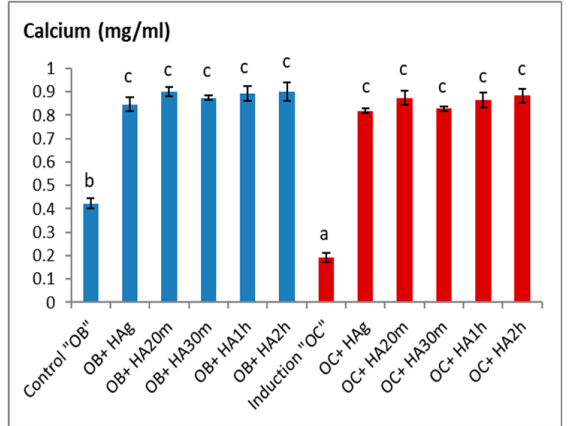

(c)

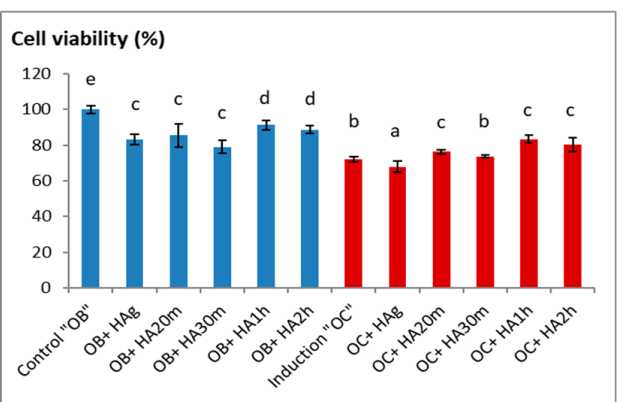

(e)

Figure 7. The effect of different HA discs on (The response of osteoblast and osteoclast cells to different HA discs treatment): (a) osteocalcin concentration, (b) alkaline phosphatase (ALP) concentration, (c) intracellular calcium concentration, (d) tartrate-resistant acid phosphatase (TRAcP) concentration, (e) cell viability. In each bar, means with different letters are significantly different from each other where (a) the lowest mean, means the same letters are significantly similar at $p<0.05$.

As previously mentioned in the literature, osteoblastic activity is associated with serum osteocalcin, which is one of the proteins found in a relatively high concentration in bone. Osteoblast produces osteocalcin protein and a very small amount is released into the circulation [57]. Glucocorticoids administration cause osteoblast cells death that is associated with the liberation of the cellular content into serum and consequently an increase of osteocalcin level [58].

The HA ceramics addition increases the adhesion of osteoblast to their surface and stimulates the osteogenesis as well as prevents osteoblastic cell death by glucocorticoid leading to a decrease in osteocalcin level [59]. The ALP enzyme which is a membranebound enzyme plays an important role in bone mineralization through the hydrolysis of phosphate esters as well as pyrophosphates which are accounted as inhibitors of bone mineralization. During active bone formation, the level of ALP which is a byproduct of osteoblast activity is increased [60]. When HA discs were added to cells, calcium concentration is increased due to the dynamic dissolution of calcium ions from hydroxyapatite. These results are consistent with the theory reported in Tang Z. et al. (2018). The extracellular calcium ions $\mathrm{Ca}^{2+}$ could act as a carrier of biological signals for bone marrow progenitor cells or premature osteoblast cells at the site of bone resorption after which it stimulates these progenitor cells' maturation into osteoblast cells to produce new bone [60].

TRAcP is an enzyme specifically expressed in high amounts by osteoclasts cells and has been evaluated as a bone resorption marker. Therefore, the elevated level of TRAcP in OC indicates the formation of osteoclast cells and the occurrence of bone resorption mechanism [61]. This also proves that glucocorticoid addition induces osteoblast death and osteoclast formation. Moreover, Wang et al. (2004) and Costa et al. (2013) proved that the HA ceramics sintered at higher temperature significantly enhance osteoblast function by inducing the bone formation markers while suppressing the osteoclast activity $[40,62]$. Costa et al. (2013) reported that hydroxyapatite ceramics negatively induce the TRAcP level [40]. Furthermore, it is mentioned that the HA ceramics sintered at higher temper- 
atures and for a long time affected cell proliferation [62]. Furthermore, changes in the surface topography of hydroxyapatite after sintering influence cell differentiation and proliferation [40].

\subsubsection{Effect of Hydroxyapatite Treatment in Bone-MSC and Osteoblast Death Signals}

Table 4 shows that all treatments of OB cells did not affect bone mesenchymal cell (MSCs-are precursors of the osteoblasts) signals (CD90 and CD 105 as well as PARR- y) and osteoblast death cell signals (GSK3 $\beta$ pS9, GSK3 $\beta$, MAPK, and $\beta$-catenin) compared to control OB cells at $p<0.05$. Furthermore, the ratio of OB cells treated with different HA discs showed the same GSK3 $\beta$ pS9/GSK3 $\beta$ level except for the treatment with HA20m that showed the lowest ratio level at $p<0.05$. Addition of cortisone increased mesenchymal stem cells (MSCs) markers (CD90 and CD 105) as well as adipocytes marker (PARR- $y$ ) and cellular death markers (GSK3 $\beta$ pS9, GSK3 $\beta$, MAPK, $\beta$-catenin, and the ratio GSK3 $\beta$ pS9/GSK3 $\beta$ ) to their maximum levels at $p<0.05$. The treatment of OC cells with different HA discs decreased all tested markers and the GSK3 $\beta$ pS9/GSK3 $\beta$ ratio when compared to OC levels. However, all these parameters were higher than that of OB cells at $p<0.05$. MSCs are progenitor cells that subsequently differentiate into mature adipocytes or mature osteoblasts. Ishida and Heersche 1998 along with our study results showed that the effectiveness of glucocorticoid depends on GCs concentrations i.e., low concentrations of GCs stimulate osteoblast differentiation and increase bone formation. While elevated concentrations of GCs stimulate osteoclast formation and osteoblast apoptosis [39]. Therefore, the elevated concentration of cortisone differentiates the MSCs into adipocytes and participates in osteoclast formation. The treatment with all different HA discs carried on osteoclastic cells decreased CD90, CD 105, and PARR- $y$, indicating the differentiation of MSC into osteoblast or the prevention of osteoclast formation.

Table 4. Effect of different HA discs on bone-MSC and osteoblast death markers of cortisone-induced osteoclast formation.

\begin{tabular}{|c|c|c|c|c|c|c|c|c|}
\hline Groups & $\begin{array}{l}\text { CD90 } \\
\text { (ng/mg) }\end{array}$ & $\begin{array}{l}\text { CD105 } \\
\text { (ng/mg) }\end{array}$ & $\begin{array}{l}\text { PARR- } y \\
\text { (pg/mg) }\end{array}$ & $\begin{array}{l}\text { P38-MAPK } \\
\text { (ng/mg) }\end{array}$ & $\begin{array}{l}\text { GSK3 } \beta \text { pS9 } \\
(\mu \mathrm{g} / \mathrm{mg})\end{array}$ & $\begin{array}{l}\text { GSK3 } \beta \\
(\mu \mathrm{g} / \mathrm{mg})\end{array}$ & $\begin{array}{l}\text { GSK3 } 3 \text { pS9 } \\
\text { /GSK3 } \beta\end{array}$ & $\begin{array}{l}\text { B.catenin } \\
\text { (pg/mg) }\end{array}$ \\
\hline $\begin{array}{l}\text { Control } \\
\text { OB }\end{array}$ & $3.21 \pm 0.01^{\mathrm{A}}$ & $1.48 \pm 0.07^{\mathrm{A}}$ & $16.44 \pm 1.3^{\mathrm{A}}$ & $0.35 \pm 0.01^{\mathrm{A}}$ & $3.3 \pm 0.02^{\mathrm{A}}$ & $5.6 \pm 0.13^{\mathrm{A}}$ & $0.59 \pm 0.06^{\mathrm{B}}$ & $1.35 \pm 0.005^{\mathrm{A}}$ \\
\hline OB HAg & $3.21 \pm 0.02^{\mathrm{A}}$ & $1.53 \pm 0.02^{\mathrm{A}}$ & $16.93 \pm 2.3^{\mathrm{A}}$ & $0.33 \pm 0.02^{\mathrm{A}}$ & $3.2 \pm 0.05^{\mathrm{A}}$ & $5.3 \pm 0.12^{A}$ & $0.60 \pm 0.07^{\mathrm{B}}$ & $1.36 \pm 0.030^{\mathrm{A}}$ \\
\hline OB HA20m & $3.23 \pm 0.02 \mathrm{~A}$ & $1.46 \pm 0.09^{\mathrm{A}}$ & $17.62 \pm 0.9^{\mathrm{A}}$ & $0.32 \pm 0.03^{\mathrm{A}}$ & $2.8 \pm 0.09^{\mathrm{A}}$ & $5.6 \pm 0.21^{\mathrm{A}}$ & $0.500 \pm 0.07^{\mathrm{A}}$ & $1.37 \pm 0.007^{\mathrm{A}}$ \\
\hline OB HA30m & $3.19 \pm 0.02^{\mathrm{A}}$ & $1.58 \pm 0.05^{\mathrm{A}}$ & $16.23 \pm 1.6^{\mathrm{A}}$ & $0.34 \pm 0.02^{\mathrm{A}}$ & $3.1 \pm 0.01^{\mathrm{A}}$ & $5.1 \pm 0.17^{\mathrm{A}}$ & $0.61 \pm 0.04^{\mathrm{B}}$ & $1.32 \pm 0.003^{\mathrm{A}}$ \\
\hline OB HA1h & $3.23 \pm 0.01 \mathrm{~A}$ & $1.51 \pm 0.20^{\mathrm{A}}$ & $15.31 \pm 1.8^{\mathrm{A}}$ & $0.36 \pm 0.01 \mathrm{~A}$ & $3.3 \pm 0.01^{\mathrm{A}}$ & $5.5 \pm 0.15^{\mathrm{A}}$ & $0.60 \pm 0.08^{B}$ & $1.38 \pm 0.001^{\mathrm{A}}$ \\
\hline OB HA2h & $3.21 \pm 0.03^{\mathrm{A}}$ & $1.45 \pm 0.08^{\mathrm{A}}$ & $16.13 \pm 2.8^{\mathrm{A}}$ & $0.39 \pm 0.04^{\mathrm{A}}$ & $3.4 \pm 0.11^{\mathrm{A}}$ & $5.9 \pm 0.23^{\mathrm{A}}$ & $0.58 \pm 0.04^{\mathrm{B}}$ & $1.36 \pm 0.003^{\mathrm{A}}$ \\
\hline $\begin{array}{l}\text { Induction } \\
\text { OC }\end{array}$ & $7.32 \pm 0.08^{G}$ & $6.85 \pm 0.32 \mathrm{~F}$ & $54.24 \pm 1.6^{\mathrm{D}}$ & $1.73 \pm 0.12^{\mathrm{F}}$ & $15.7 \pm 1.2^{\mathrm{E}}$ & $11.9 \pm 1.80^{\mathrm{E}}$ & $1.32 \pm 0.09 \mathrm{G}$ & $3.97 \pm 0.023^{\mathrm{F}}$ \\
\hline OC HAg & $6.20 \pm 0.31^{\mathrm{F}}$ & $5.11 \pm 0.24^{\mathrm{D}}$ & $42.31 \pm 2.7^{C}$ & $1.63 \pm 0.23^{\mathrm{E}}$ & $11.3 \pm 2.3^{\mathrm{D}}$ & $14.3 \pm 1.10^{\mathrm{D}}$ & $0.790 \pm 0.04^{\mathrm{F}}$ & $3.72 \pm 0.120^{\mathrm{E}}$ \\
\hline OC HA20m & $3.94 \pm 0.07^{\mathrm{B}}$ & $2.73 \pm 0.21^{\mathrm{B}}$ & $20.36 \pm 0.8^{B}$ & $0.65 \pm 0.03^{\mathrm{B}}$ & $6.1 \pm 0.21^{\mathrm{B}}$ & $8.92 \pm 0.30^{B}$ & $0.68 \pm 0.01^{\mathrm{C}}$ & $1.98 \pm 0.008^{\mathrm{B}}$ \\
\hline OC HA30m & $4.08 \pm 0.04^{C}$ & $3.01 \pm 0.19^{\mathrm{B}}$ & $18.73 \pm 3.1 \mathrm{AB}$ & $0.77 \pm 0.02^{\mathrm{C}}$ & $7.9 \pm 0.32^{C}$ & $10.9 \pm 0.50^{\mathrm{C}}$ & $0.72 \pm 0.02^{\mathrm{D}}$ & $2.1 \pm 0.003^{C}$ \\
\hline OC HA1h & $4.98 \pm 0.05^{\mathrm{D}}$ & $4.17 \pm 0.34^{C}$ & $18.64 \pm 0.9 \mathrm{AB}$ & $0.93 \pm 0.07^{\mathrm{D}}$ & $9.3 \pm 0.78^{\mathrm{D}}$ & $11.9 \pm 0.70^{C}$ & $0.78 \pm 0.03^{\mathrm{E}}$ & $2.87 \pm 0.009 \mathrm{D}$ \\
\hline OC HA2h & $5.92 \pm 0.10^{\mathrm{E}}$ & $4.93 \pm 0.27^{\mathrm{D}}$ & $40.83 \pm 3.7^{C}$ & $1.61 \pm 0.21^{\mathrm{E}}$ & $10.8 \pm 1.8^{\mathrm{D}}$ & $13.6 \pm 0.90^{\mathrm{D}}$ & $0.79 \pm 0.01^{\mathrm{F}}$ & $3.63 \pm 0.015^{\mathrm{E}}$ \\
\hline
\end{tabular}

The results are the means $\pm S D$ in each group. In each column, means with different letters $\left({ }^{A}, B, C, D, E\right.$ and, $\left.{ }^{F}\right)$ are significantly different from each other where $\left({ }^{\mathrm{A}}\right)$ the lowest mean, means with the same letters are significantly similar at $p<0.05$. OB is osteoblast cells, and OC is osteoclast cells.

Moreover, the addition of cortisone to osteoblast cells for 21 days increased GSK3 $\beta$, GSK3 $\beta$ pS9, and MAPK. Several studies show that osteoporosis formation increased GSK3 $\beta$ induction and phosphorylation (GSK3 $\beta$ pS9) which in turn phosphorylates and accumulates $\beta$-catenin in cell cytoplasm finally inhibiting the Wnt pathway [14,15]. Moreover, the induction of MAPK stimulates the formation of PARP- $y$ that activates MSC differentiation into adipocytes. Moreover, MAPK phosphorylates GSK3 $\beta$ which in turn phosphorylates and accumulates $\beta$-catenin leading to osteoclast formation and osteoblasts cell death $[59,63]$. Altogether, cortisone not only affects the Wnt/catenin pathway but also induces inflammation microenvironment which promoted $\beta$-catenin accumulation. Moreover, $\beta$-catenin accumulation occurs when adipocytes formation takes place to suppress the noncanonical Wnt $/ \mathrm{Ca}\left({ }^{2+}\right)$ pathway which consequently arrests osteoblast formation and reduces the osteogenic differentiation. Treatment with all different HA discs conducted on OC 
improved the tested parameters, nonetheless, did not normalize them as mentioned before by several authors who stated that the treatment with different calcium/phosphorus forms induced bone formation through Wnt/catenin pathway $[14,15]$. Finally, the obtained results proved that the treatment with the microwave hybrid sintered HA (HA20m) was the best at $p<0.05$.

\section{Conclusions}

Microwave hybrid sintering speeds up heating processes, saves energy, and improves chemical and biochemical properties of nanorod hydroxyapatite compared to conventional sintering. Microwave hybrid sintering cause a uniform growth of HA grains with highest crystallinity $(88.72 \%)$ at HA30m. Moreover, the $\mathrm{Ca} / \mathrm{P}$ atomic ratio was increased until reaching the stoichiometric value of $(\approx 1.67)$ in microwave hybrid sintered samples (HA20m and HA30m). Hydrocortisone can suppress osteoblast function and thus reduce bone remodeling and impair bone tissue repair. These occur by increasing apoptosis in osteoblasts through the production of reactive oxygen species (ROS), inhibition of bone formation transcription factors, and accumulation of $\beta$-catenin leading to suppression of the Wnt / $\beta$-catenin pathway. Nanorod hydroxyapatite enhanced osteoblast functions proliferation, alkaline phosphates, calcium synthesis, bone formation transcription factors production that correlate with decreased $\beta$-catenin accumulation leading to activation of the Wnt/ $\beta$-catenin pathway. The resorptive activity of osteoclasts cultured with nanorod HA was weaker than that of control osteoclastic cells. In addition, cell adhesion and proliferation were enhanced by the presence of HA. Therefore, microwave hybrid sintered nanorod hydroxyapatite may serve as a valuable scaffold for osteoporotic bone regeneration.

Author Contributions: N.Z.S. participated in methodology revision and refinement, manuscript preparation, and work supervision, M.Y.K. participated in idea and methods design, performed all experiments work, data collection and analyses, manuscript writing, and original draft preparation. N.A.T. participated in data analyses and interpretation, manuscript writing, and original draft preparation. M.M.A.E.-L. is the grant Co-PI and she participated in idea design, work supervision, manuscript review, and editing. D.A.G. is the grant PI and she participated in idea design, work supervision, methods design, data collection and analyses, manuscript writing, and original draft preparation. All authors have read and agreed to the published version of the manuscript.

Funding: This research was completely funded by science, technology and innovation funding authority (STIFA), Egypt, grant number 25845". The APC is funded by the authors.

Institutional Review Board Statement: The study was conducted according to the guidelines of the Declaration of Helsinki, and approved by Ethics Committee of Pharmaceutical and Fermentation Industry Development Center (PFIDC) institutional animal care and use committees (IACUSs) (IACUC\#34-3C-0719).

Informed Consent Statement: Not Applicable.

Data Availability Statement: The data presented in this study are contained within the article.

Acknowledgments: We gratefully thank E/Mohamed Abd El-Salam from Alexandria Mineral Oils Company (AMOC), Egypt for his technical support, may his soul rest in peace (1974-2021).

Conflicts of Interest: The authors declare no conflict of interest.

\section{References}

1. Gomes, D.S.; Santos, A.M.C.; Neves, G.A.; Menezes, R.R. A brief review on hydroxyapatite production and use in biomedicine. Ceramica 2019, 65, 282-302. [CrossRef]

2. Kuśnieruk, S.; Wojnarowicz, J.; Chodara, A.; Chudoba, T.; Gierlotka, S.; Lojkowski, W. Influence of hydrothermal synthesis parameters on the properties of hydroxyapatite nanoparticles. Beilstein J. Nanotechnol. 2016, 7, 1586-1601. [CrossRef] [PubMed]

3. Boskey, A.L. Bone composition: Relationship to bone fragility and antiosteoporotic drug effects. Bonekey Rep. 2013, 2, 447. [CrossRef]

4. Gheita, T.A.; Hammam, N. Epidemiology and awareness of osteoporosis: A viewpoint from the Middle East and North Africa. Int. J. Clin. Rheumatol 2018, 13, 134-147. 
5. Liu, J.; Curtis, E.M.; Cooper, C.; Harvey, N.C. State of the art in osteoporosis risk assessment and treatment. J. Endocrinol. Investig. 2019, 42, 1149-1164. [CrossRef] [PubMed]

6. Mowafy, M.A.; Kamel, L.M.; Hamed, S.T.; Mohamed, D.A.; Taha, Y.M. Osteoporosis risk prediction among a group of postmenopausal females: A case-control study. Egypt. Fam. Med. J. 2019, 3, 65-82. [CrossRef]

7. Ukon, Y.; Makino, T.; Kodama, J.; Tsukazaki, H.; Tateiwa, D.; Yoshikawa, H.; Kaito, T. Molecular-based treatment strategies for osteoporosis: A literature review. Int. J. Mol. Sci. 2019, 20, 2557. [CrossRef] [PubMed]

8. Chen, J.; Sambrook, P. Antiresorptive therapies for osteoporosis: A clinical overview. Nat. Rev. Endocrinol. 2011, 8, 81-91. [CrossRef] [PubMed]

9. O’Brien, C.A.; Jia, D.; Plotkin, L.I.; Bellido, T.; Powers, C.C.; Stewart, S.A.; Manolagas, S.C.; Weinstein, R.S. Glucocorticoids act directly on osteoblasts and osteocytes to induce their apoptosis and reduce bone formation and strength. Endocrinology 2004, 145, 1835-1841. [CrossRef] [PubMed]

10. Weinstein, R.S. Glucocorticoid-induced osteoporosis and osteonecrosis. Endocrinol. Metab. Clin. N. Am. 2012, 41, 595-611. [CrossRef]

11. Hench, L.L. Bioceramics: From concept to clinic. J. Am. Ceram. Soc. 1991, 74, 1487-1510. [CrossRef]

12. Kolos, E.C.; Ruys, A.J. Osteoblast attachment to hydroxyapatite micro-tube scaffolds. J. Mater. Sci. Mater. Med. 2014, 25, 1801-1817. [CrossRef] [PubMed]

13. Ginebra, M.P.; Espanol, M.; Maazouz, Y.; Bergez, V.; Pastorino, D. Bioceramics and bone healing. EFORT Open Rev. 2018, 3 , 173-183. [CrossRef] [PubMed]

14. Wang, Y.; Pan, J.; Zhang, Y.; Li, X.; Zhang, Z.; Wang, P.; Qin, Z.; Li, J. Wnt and Notch signaling pathways in calcium phosphateenhanced osteogenic differentiation: A pilot study. J. Biomed. Mater. Res. Part B Appl. Biomater. 2019, 107, 149-160. [CrossRef]

15. Moorer, M.C.; Riddle, R.C. Regulation of osteoblast metabolism by Wnt signaling. Endocrinol. Metab. 2018, 33, 318-330. [CrossRef]

16. Rial, R.; González-Durruthy, M.; Liu, Z.; Ruso, J.M. Advanced materials based on nanosized hydroxyapatite. Molecules 2021, 26, 3190. [CrossRef]

17. Tas, A.C. Combustion synthesis of calcium phosphate bioceramic powders. J. Eur. Ceram. Soc. 2000, 20, 2389-2394. [CrossRef]

18. Shah, R.K.; Fahmi, M.N.; Mat, A.H.; Zainal, A.A. The synthesis of hydroxyapatite through the precipitation method. Med. J. Malaysia 2004, 59, 75-76.

19. Isa, N.N.C.; Mohd, Y.; Yury, N. Electrochemical deposition and characterization of hydroxyapatite (HAp) on titanium substrate. APCBEE Procedia 2012, 3, 46-52. [CrossRef]

20. Fathi, M.; Hanifi, A. Evaluation and characterization of nanostructure hydroxyapatite powder prepared by simple Sol-Gel method. Mater. Lett. 2007, 61, 3978-3983. [CrossRef]

21. Earl, J.S.; Wood, D.J.; Milne, S.J. Hydrothermal synthesis of hydroxyapatite. J. Phys. Conf. Ser. 2006, 26, 268-271. [CrossRef]

22. Lak, A.; Mazloumi, M.; Mohajerani, M.S.; Zanganeh, S.; Shayegh, M.R.; Kajbafvala, A.; Arami, H.; Sadrnezhaad, S.K. Rapid formation of mono-dispersed hydroxyapatite nanorods with narrow-size distribution via microwave irradiation. J. Am. Ceram. Soc. 2008, 91, 3580-3584. [CrossRef]

23. Eliaz, N.; Metoki, N. Calcium phosphate bioceramics: A review of their history, structure, properties, coating technologies and biomedical applications. Materials 2017, 10, 334. [CrossRef] [PubMed]

24. Corrales, L.P.; Esteves, M.L.; Vick, J.E. Scaffold design for bone regeneration. Journal of nanoscience and nanotechnology. J. Nanosci. Nanotechnol. 2014, 14, 15-56. [CrossRef] [PubMed]

25. Ramesh, S.; Aw, K.L.; Tolouei, R.; Amiriyan, M.; Tan, C.Y.; Hamdi, M.; Purbolaksono, J.; Hassan, M.A.; Teng, W.D. Sintering properties of hydroxyapatite powders prepared using different methods. Ceram. Int. 2013, 39, 111-119. [CrossRef]

26. Abdelrazek, K. Advanced sintering of nano-ceramic materials. In Ceramic Materials: Progress in Modern Ceramics; IntechOpen: London, UK, 2012.

27. Menezes, R.; Souto, P.; Kiminami, R.H. Microwave hybrid fast sintering of porcelain bodies. J. Mater. Process. Technol. 2007, 190, 223-229. [CrossRef]

28. Gamit, D.N.; Chudasama, M.K. Size-effect in microwave processing of engineering materials-A review. J. Mech. Eng. Sci. 2020, 14, 6770-6788. [CrossRef]

29. Ali, A.F.; Alrowaili, Z.A.; El-Giar, E.M.; Ahmed, M.M.; El-Kady, A.M. Novel green synthesis of hydroxyapatite uniform nanorods via microwave-hydrothermal route using licorice root extract as template. Ceram. Int. 2021, 47, 3928-3937. [CrossRef]

30. Fang, Y.; Agrawal, D.K.; Roy, D.M.; Roy, R. Microwave sintering of hydroxyapatite ceramics. J. Mater. Res. 1994, 9, 180-187. [CrossRef]

31. Faeghinia, A.; Ebadzadeh, T. Effect of microwave conditions on sintering of hydroxyapatite ceramics. Sci. Sinter. 2020, 52, 469-479. [CrossRef]

32. Sahu, S.; Mehra, D.; Agarwal, R. Characterization and thermal analysis of hydroxyapatite bioceramic powder synthesized by Sol-Gel technique. IJAST J. 2012, 3, 281-289.

33. Venkateswarlu, K.; Chandra Bose, A.; Rameshbabu, N. X-ray peak broadening studies of nanocrystalline hydroxyapatite by Williamson Hall analysis. Phys. B Condens. Matter 2010, 405, 4256-4261. [CrossRef]

34. Sathiyavimal, S.; Vasantharaj, S.; LewisOscar, F.; Pugazhendhi, A.; Subashkumar, R. Biosynthesis and characterization of hydroxyapatite and its composite (hydroxyapatite-gelatin-chitosan-fibrin-bone ash) for bone tissue engineering applications. Int. J. Biol. Macromol. 2019, 129, 844-852. [CrossRef] [PubMed] 
35. Ungureanu, D.; Angelescu, N.; Ion, R.-M.; Elena Valentina, S.; Rizescu, C. Synthesis and characterization of hydroxyapatite nanopowders by chemical precipitation. In Recent Researches in Communications, Automation, Signal Processing, Nanotechnology, Astronomy and Nuclear Physics; WSEAS Press: London, UK, 2011.

36. Deligianni, D.D.; Katsala, N.D.; Koutsoukos, P.G.; Missirlis, Y.F. Effect of surface roughness of hydroxyapatite on human bone marrow cell adhesion, proliferation, differentiation and detachment strength. Biomaterials 2000, 22, 87-96. [CrossRef]

37. Singh, R.; Tan, C.Y.; Bhaduri, S.; Teng, W. Rapid densification of nanocrystalline hydroxyapatite for biomedical applications. Ceram. Int. 2007, 33, 1363-1367. [CrossRef]

38. Stern, A.R.; Stern, M.M.; Van Dyke, M.E.; Jähn, K.; Prideaux, M.; Bonewald, L.F. Isolation and culture of primary osteocytes from the long bones of skeletally mature and aged mice. Biotechniques 2012, 52, 361-373. [CrossRef]

39. Ishida, Y.; Heersche, J.N.M. Glucocorticoid-induced osteoporosis: Both in vivo and in vitro concentrations of glucocorticoids higher than physiological levels attenuate osteoblast differentiation. J. Bone Miner. Res. 1998, 13, 1822-1826. [CrossRef]

40. Costa, D.O.; Prowse, P.D.H.; Chrones, T.; Sims, S.M.; Hamilton, D.W.; Rizkalla, A.S.; Dixon, S.J. The differential regulation of osteoblast and osteoclast activity by surface topography of hydroxyapatite coatings. Biomaterials 2013, 34, 7215-7226. [CrossRef]

41. Xiao, D.; Zhang, J.; Zhang, C.; Barbieri, D.; Yuan, H.; Moroni, L.; Feng, G. The role of calcium phosphate surface structure in osteogenesis and the mechanisms involved. Acta Biomater. 2020, 106, 22-33. [CrossRef]

42. Mosmann, T. Rapid colorimetric assay for cellular growth and survival: Application to proliferation and cytotoxicity assays. $J$. Immunol. Methods 1983, 65, 55-63. [CrossRef]

43. Gregory, C.A.; Grady Gunn, W.; Peister, A.; Prockop, D.J. An Alizarin red-based assay of mineralization by adherent cells in culture: Comparison with cetylpyridinium chloride extraction. Anal. Biochem. 2004, 329, 77-84. [CrossRef]

44. Huang, W.; Yang, S.; Shao, J.; Li, Y.P. Signaling and transcriptional regulation in osteoblast commitment and differentiation. Front. Biosci. 2007, 12, 3068-3092. [CrossRef] [PubMed]

45. Wilcock, C.J.; Gentile, P.; Hatton, P.V.; Miller, C.A. Rapid mix preparation of bioinspired nanoscale hydroxyapatite for biomedical applications. J. Vis. Exp. 2017, 120, e55343. [CrossRef]

46. Kim, J.H.; Kim, S.H.; Kim, H.K.; Akaike, T.; Kim, S.C. Synthesis and characterization of hydroxyapatite crystals: A review study on the analytical methods. J. Biomed. Mater. Res. 2002, 62, 600-612. [CrossRef]

47. Rapacz-Kmita, A.; Paluszkiewicz, C.; Slósarczyk, A.; Paszkiewicz, Z. FTIR and XRD investigations on the thermal stability of hydroxyapatite during hot pressing and pressureless sintering processes. J. Mol. Struct. 2005, 744-747, 653-656. [CrossRef]

48. Goranova, K.L.; Kattenhøj Sloth Overgaard, A.K.; Gitsov, I. Hydroxyapatite-poly(D,L-lactide) nanografts. synthesis and characterization as bone cement additives. Molecules 2021, 26, 424. [CrossRef]

49. Aarthy, S.; Thenmuhil, D.; Dharunya, G.; Manohar, P. Exploring the effect of sintering temperature on naturally derived hydroxyapatite for bio-medical applications. J. Mater. Sci. Mater. Med. 2019, 30, 21. [CrossRef]

50. Raynaud, S.; Champion, E.; Bernache-Assollant, D. Calcium phosphate apatites with variable Ca/P atomic ratio II. Calcination and sintering. Biomaterials 2002, 23, 1073-1080. [CrossRef]

51. Abifarin, J.K.; Obada, D.O.; Dauda, E.T.; Dodoo-Arhin, D. Experimental data on the characterization of hydroxyapatite synthesized from biowastes. Data Br. 2019, 26, 104485. [CrossRef]

52. Yudyanto; Azizah, E.N.; Mufti, N.; Hartatiek; Hidayat, N.; Kurniawan, R. Effect of stirring duration on hardness and antibacterial characteristics of Polyethylene Glycol-Hydroxyapatite nanocomposites. IOP Conf. Ser. Mater. Sci. Eng. 2019, 515, 012073. [CrossRef]

53. Curran, D.J.; Fleming, T.J.; Towler, M.R.; Hampshire, S. Mechanical parameters of strontium doped hydroxyapatite sintered using microwave and conventional methods. J. Mech. Behav. Biomed. Mater. 2011, 4, 2063-2073. [CrossRef] [PubMed]

54. Song, J.; Liu, Y.; Zhang, Y.; Jiao, L. Mechanical properties of hydroxyapatite ceramics sintered from powders with different morphologies. Mater. Sci. Eng. A 2011, 528, 5421-5427. [CrossRef]

55. Taylor, S.E.B.; Shah, M.; Orriss, I.R. Generation of rodent and human osteoblasts. Bonekey Rep. 2014, 3, 585. [CrossRef] [PubMed]

56. Roodman, G.D. Cell biology of the osteoclast. Exp. Hematol. 1999, 27, 1229-1241. [CrossRef]

57. Hampson, G. Biochemical Markers in Bone Diseases BT-Radionuclide and Hybrid Bone Imaging; Fogelman, I., Gnanasegaran, G., van der Wall, H., Eds.; Springer: Berlin/Heidelberg, Germany, 2012; pp. 109-132.

58. Yun, S.-I.; Yoon, H.-Y.; Jeong, S.-Y.; Chung, Y.-S. Glucocorticoid induces apoptosis of osteoblast cells through the activation of glycogen synthase kinase 3beta. J. Bone Miner. Metab. 2009, 27, 140-148. [CrossRef]

59. Jing, Z.; Wang, C.; Yang, Q.; Wei, X.; Jin, Y.; Meng, Q.; Liu, Q.; Liu, Z.; Ma, X.; Liu, K.; et al. Luteolin attenuates glucocorticoidinduced osteoporosis by regulating ERK/Lrp-5/GSK-3ß signaling pathway in vivo and in vitro. J. Cell. Physiol. 2019, 234, 4472-4490. [CrossRef]

60. Tang, Z.; Li, X.; Tan, Y.; Fan, H.; Zhang, X. The material and biological characteristics of osteoinductive calcium phosphate ceramics. Regen. Biomater. 2018, 5, 43-59. [CrossRef] [PubMed]

61. Mederle, O.A.; Balas, M.; Ioanoviciu, S.D.; Gurban, C.V.; Tudor, A.; Borza, C. Correlations between bone turnover markers, serum magnesium and bone mass density in postmenopausal osteoporosis. Clin. Interv. Aging 2018, 13, 1383-1389. [CrossRef] 
62. Wang, C.; Duan, Y.; Markovic, B.; Barbara, J.; Rolfe Howlett, C.; Zhang, X.; Zreiqat, H. Proliferation and bone-related gene expression of osteoblasts grown on hydroxyapatite ceramics sintered at different temperature. Biomaterials 2004, 25, 2949-2956. [CrossRef] [PubMed]

63. Rodríguez-Carballo, E.; Gámez, B.; Ventura, F. p38 MAPK signaling in osteoblast differentiation. Front. Cell Dev. Biol. 2016, 4, 40. [CrossRef] 